\title{
A review on the ethnomedicinal uses, phytochemistry and pharmacology of plant species belonging to Kaempferia L. genus (Zingiberaceae)
}

Ngoc Khanh Pham ${ }^{1,2,3^{*}}$, Hoang Tuan Nguyen ${ }^{2}$, Quoc Binh Nguyen ${ }^{4}$

1 Institute of Natural Products Chemistry (INPC), Vietnam Academy of Science and Technology, Cau Giay, Hanoi, Vietnam

2 Hanoi University of Pharmacy, Hoan Kiem, Hanoi, Vietnam

3 College of Pharmacy, Dongguk University, Goyang, Korea

4 Vietnam National Museum of Nature, Vietnam Academy of Science and Technology, Cau Giay, Hanoi, Vietnam

*Corresponding author:

Ngoc Khanh Pham

khanhngocpham@inpc.vast.vn

Keywords:

Kaempferia L.; Kaempferia galanga;

K. parviflora; K. pandurata;

K. daklakensis; Thailand;

Vietnam; South East Asia

\begin{abstract}
Kaempferia L. is a genus commonly distributed in Asian countries including China, India, Thailand, Myanmar, Malaysia, Indonesia, Laos, Cambodia and Vietnam, where these species are popularly used as traditional medicines for different ailments comprising infective diseases, wound infection, cough, pain and digestion disorders on chemical composition of Kaempferia plants revealed the presence of natural compounds classified in monoterpenoids, diterpenoids, flavonoids, phenolic glycosides, cyclohexane oxide derivatives, diarylheptanoids and essential oil with various biological properties, which are valuable for discovery of new natural-derived therapeutic drugs and applications for the human beings. This study is aimed to review the chemical, ethnobotanical and pharmacological properties of the plants belonging to Kaempferia genus growing in Asian countries and especially in South East Asia.
\end{abstract}

\section{INTRODUCTION}

Kaempferia, is a medium - sized genus of about 60 plant species belonging to Zingiberaceae ${ }^{1}$ that is one of the major tropical plant families with many members commonly used as ornaments, spices and as medicinal herbs ${ }^{2}$. The generic name of the genus memorializes Engelbert Kaempfer (1651-1716), who was a known German naturalist and physician and explorer writer ${ }^{3}$. There are about 40 Kaempferia species names were officially accepted (Table $1 \mathrm{~S}$, Supporting information $)^{4}$. The genus mainly distributes in East Asia to China, India, Bangladesh and Southeast Asia like Thailand, Myanmar, Malaysia, Indonesia, Philippines, Laos, Cambodia and Vietnam. The most widespread Kaempferia species are $K$. galanga, $K$. parviflora, and $K$. rotunda, $K$. augustiflora, etc. (Table 1). These species distribute in many countries and territories and are popularly used as traditional medicines for different ailments including infective diseases, wound infection, cough, pain and digestion disorders. Research on chemical composition of Kaempferia plants revealed the presence of natural compounds classified in monoterpenoids, diterpenoids, flavonoids, phenolic glycosides, cyclohexane oxide derivatives, diarylheptanoids and essential oil with various biological properties, which provide these species as a valuable medicinal resource for new natural-derived therapeutic applications for the human beings. This study is aimed to review the ethnobotanical uses, morphological, chemical, and pharmacological properties of the plants belonging to Kaempferia species. The application of the species in modern life is also reported. https://www.pharmacy.mahidol.ac.th/journal/ (C) Faculty of Pharmacy, Mahidol University (Thailand) 2021 


\section{MATERIALS AND METHODS}

Different methods were used to collect information about ethnomedicinal uses, phytochemistry and pharmacological properties of Kaempferia species.

Accepted name of the plant was collected by using the website www.theplantlist.org (The Plant List, 2019). Worldwide databases including Science Direct, Scopus, Pubmed, Google Scholar and Google Search Engine with keywords of family name, genus name, plant name and isolated natural compound names were used for literature search. Related patents were acquired from Google Patents.

Only articles containing plants collected or purchased from certified medicinal/non medicinal stores with proper identification and voucher specimen were considered for this review in accordance with previously described methods for literature search ${ }^{5}$.

\section{RESULTS AND DISCUSSION}

\subsection{Ethnobotanical use of Kaempferia L. species}

Many Kaempferia species have been reported to be used as medicinal plants in many folk medicines for treatment of various ailments including malaria, wound infection, urticarial, diabetes, cancer, herpes and allergy ${ }^{6}$.

In almost Asian traditional systems, the most common Kaempferia species was Kaempferia galanga which plays a very special role as medicinal plant. In India, it is a component of over 59 in ayrurvedic drug formulations to cure asthma, malaria, skin disease, bronchitis, wounds and splenic disorders? It is also used as perfumery, cosmetics and spice ingredients ${ }^{8}$. There are 15 Kaempferia enumerated for Thailand ${ }^{9}$, of which 12/15 Kaempferia species were discovered by C. Picheansoonthon and his colleagues from 2008-2013 (Table 1) ${ }^{10}$.
$K$. galanga is commonly used for the treatment of dysentery, diarrhea, stomachache, swelling, cough, and rheumatism ${ }^{6}$. The dried rhizome has been used as cardiotonic and CNS stimulant $^{8}$. K. roscoeana Wall, known as "Pro pa", is used as a spice and food in Thai cuisine ${ }^{1}$. In the North and Northeast of Thailand, the rhizome of $K$. parviflora has been widely used as a traditional medicine for centuries ${ }^{11}$. The rhizomes of $K$. parviflora have been used to treat allergies, gastrointestinal disorders, and peptic ulcers $^{12}$. Among local people in the northeast of Thailand, these rhizomes have been known as health-promoting herbs, and also frequently used for treatment of gout, abscesses, colic disorder, peptic- and duodenal ulcers ${ }^{13}$.

There are 10 species in Cambodia, Laos and Vietnam ${ }^{9}$ In Vietnam, there are approximately 7 Kaempferia species which are widely cultivated and used as medicinal plants like K. galanga (local name Địa liền) for treatment of pains like stomach pain, abdominal pain, rheumatism, pain in the joints, headache, tooth pain, chest pain, also used for poor digestion, and pertussis; $K$. angustifolia is used for cough treatment; $K$. rotunda is for treatment of abdominal pain, menstrual disorder, less menstruation and dysmenorrhea (Table 1). Recently Kaempferia species have been found to demonstrate effective cancerpreventive properties. In previous papers, several Kaempferia species were described as new record of medicinal plant species for Viet Nam including K. parviflora Wall. ex Baker ${ }^{14}, K$. marginata Carey ex Roscoe $^{15}, K$. champasakensis Picheans. \& Koonterm. ${ }^{16}$ and $K$. laotica Gagnep ${ }^{17}$.

The ethnobotanical uses in different countries of Kaempferia species with their local names have been summarized in Table 1 .

Table 1. Ethnobotanical uses of several Kaempferia species.

\begin{tabular}{|c|c|c|c|c|}
\hline Species & Distribution $^{17}$ & Local name & Ethnobotanical / Traditional uses & Ref. \\
\hline $\begin{array}{l}\text { K. angustifolia } \\
\text { Roscoe }\end{array}$ & $\begin{array}{l}\text { Bangladesh, Assam, } \\
\text { Vietnam, Thailand, } \\
\text { Sumatra }\end{array}$ & $\begin{array}{l}\text { VN: Địa liền lá thơm, } \\
\text { Thiền liền lá hẹp } \\
\text { Thai: townanghang }\end{array}$ & $\begin{array}{l}\text { Vietnam: tuber is used for cough treatment. } \\
\text { Root is eaten with Piper betle leaves for } \\
\text { prevention of tooth decay. }\end{array}$ & $\begin{array}{c}18 \\
19 \\
2\end{array}$ \\
\hline $\begin{array}{l}\text { K. elegans } \\
\text { (Wall.) Baker }\end{array}$ & $\begin{array}{l}\text { Sichuan, Indochina, } \\
\text { Borneo, India, } \\
\text { Burma, Malay } \\
\text { Peninsula }\end{array}$ & VN: Ngải chúa & Vietnam: ornamental plant. & $\begin{array}{c}9 \\
2 \\
20\end{array}$ \\
\hline K. galanga $\mathrm{L}$. & $\begin{array}{l}\text { Yunnan, Assam, } \\
\text { Bangladesh, India, } \\
\text { Indochina, Vietnam, } \\
\text { Thailand, Taiwan }\end{array}$ & $\begin{array}{l}\text { Common name: Sand } \\
\text { ginger, Resurrection lily } \\
\text { Thai: Proh Hom } \\
\text { (waan horm) } \\
\text { Khmer: prâh or prâh } \\
\text { krâ-oup }\end{array}$ & $\begin{array}{l}\text { Thailand: Used as food spice. The stem is } \\
\text { used for treatment of menstrual stimulation } \\
\text { and dyspepsia, the leave are for the treatment } \\
\text { of skin infected with fungus Tinea versicolor, } \\
\text { and flower for eye diseases and seizures. The } \\
\text { dried rhizome is used as cardiotonic and CNS. } \\
\text { The extract causes CNS depression, a decrease in } \\
\text { motor activity and a decrease in respiratory rate. }\end{array}$ & 22 \\
\hline
\end{tabular}


Table 1. Ethnobotanical uses of several Kaempferia species. (cont.)

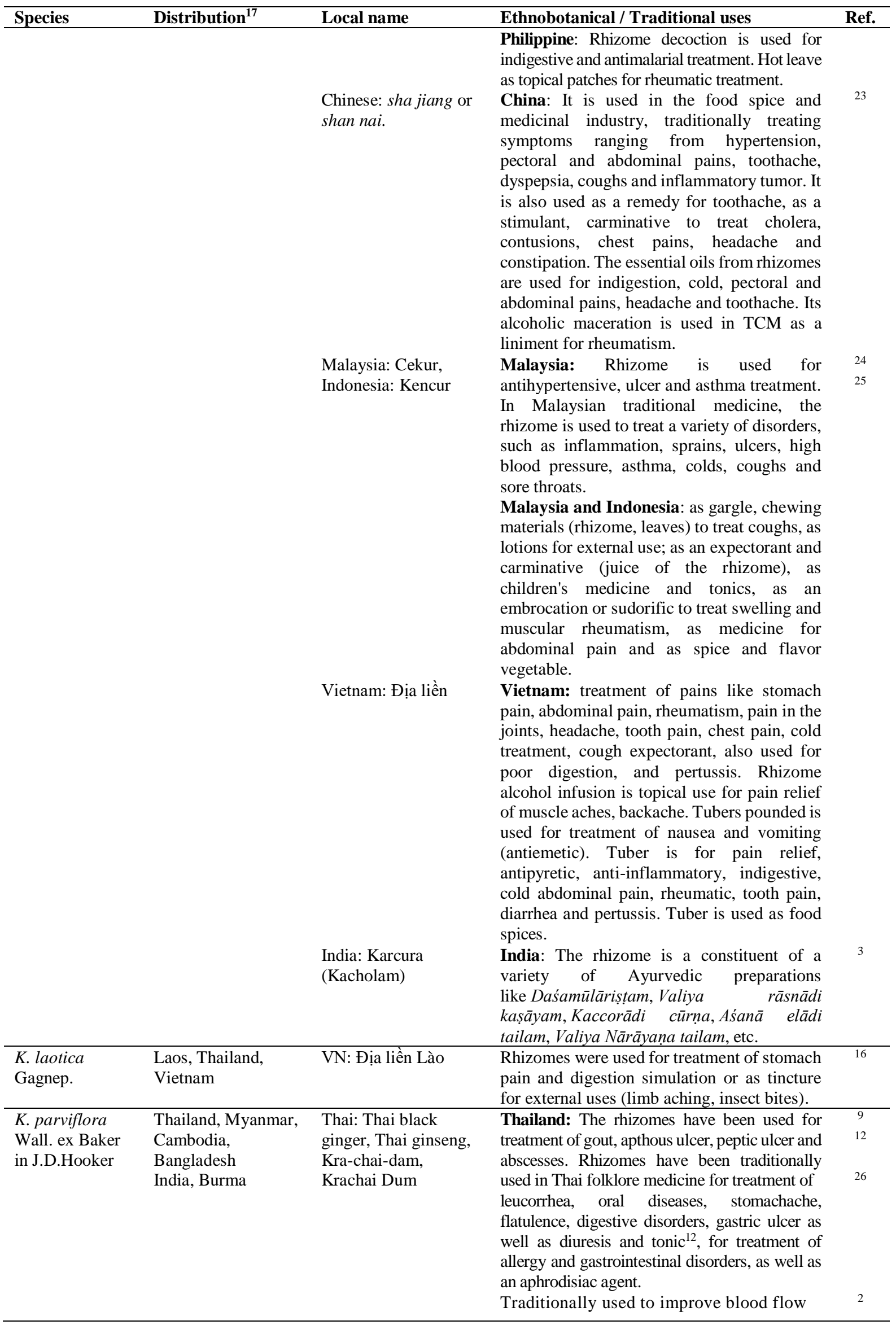


Table 1. Ethnobotanical uses of several Kaempferia species. (cont.)

\begin{tabular}{|c|c|c|c|c|}
\hline Species & Distribution $^{17}$ & Local name & Ethnobotanical / Traditional uses & Ref. \\
\hline & & Japan: Black ginger & $\begin{array}{l}\text { and treat inflammatory, allergic, and } \\
\text { gastrointestinal disorders. } \\
\text { Laos: in Laos folk medicine, it has been used } \\
\text { for lowering blood glucose levels, improving } \\
\text { blood flow and increasing vitality. } \\
\text { Japan: KP extract is commercially available } \\
\text { as a food supplement for the treatment of } \\
\text { metabolic syndrome. }\end{array}$ & \\
\hline K. pulchra & $\begin{array}{l}\text { Thailand, } \\
\text { Indonesia }\end{array}$ & Indonesia: temu kunci & $\begin{array}{l}\text { traditionally used for food and also medicinal } \\
\text { purposes for diarrhea, and for its anti- } \\
\text { mutagenic, anti-tumour, anti-inflammatory } \\
\text { activities, etc. }\end{array}$ & 29 \\
\hline $\begin{array}{l}\text { K. roscoeana } \\
\text { Wall. }\end{array}$ & Myanmar, Thailand & Thai: Pro pa & spice and food in Thai cuisine. & 6 \\
\hline K. rotunda $\mathrm{L}$. & $\begin{array}{l}\text { China (Guangdong, } \\
\text { Guangxi, Hainan, } \\
\text { Taiwan, Yunnan), } \\
\text { India, Nepal, } \\
\text { Assam, Bangladesh, } \\
\text { Indochina }\end{array}$ & $\begin{array}{l}\text { VN: Cẩm địa la, Ngải } \\
\text { máu (blood } \\
\text { Kaempferia) } \\
\text { Thai: Waan dokdin, } \\
\text { Waan som, Wan How } \\
\text { Non }\end{array}$ & $\begin{array}{l}\text { Vietnam: ornament plant; used for treatment } \\
\text { of abdominal pain, menstrual disorder, less } \\
\text { menstruation and dysmenorrhea. } \\
\text { India: rhizome: topical use, swelling and injury, } \\
\text { stomach pain treatment. Rhizomic decoction: } \\
\text { phù tay chân, tràn dịch ở khớp, ho đờm. } \\
\text { Indonesia: rhizome is used for abdominal } \\
\text { pain. Crushed whole plant with salt is to } \\
\text { reduce fever. } \\
\text { Philippine, Malaysia: rhizome is used for } \\
\text { treatment of stomach pain, skin wound } \\
\text { healing, mump and cosmetic preparation. }\end{array}$ & 31 \\
\hline
\end{tabular}

CNS: central nervous system; TCM: traditional Chinese medicine

\subsection{Morphological study}

In general, Kaempferia species are perennial rhizomic herbs ${ }^{9}$. Rhizome fragrant, roots often bearing tubers. According to Phokham et. al. ${ }^{18}$, the genus Kaempferia can be divided into two groups: the $K$. galanga group and the $K$. rotunda group, distinguished from each other by the appearing time of inflorescences. While the "spring-blooming" of $K$. rotunda group is from end of March to early May, the inflorescences of $K$. galanga group appear mostly in August to September ${ }^{18}$.

Additionally, several species of Kaempferia L. have been also reported as new finding species nowadays including K. sisaketensis Picheans. \& Koonterm, $K$. attapeuensis Picheans. \& Koonterm, $K$. grandifolia Saensouk \& Jenjitt, $K$. spoliata Sirirugsa, K. chayanii Koonterm ${ }^{19}$, K. udonensis Picheans. \& Phokham, K. picheansoonthonii Wongsuwan \& Phokham from northeastern Thailand, $K$. larsenii P. Sirirugsa sp. nov, $K$. siamensis $P$. Sirirugsa ${ }^{20}, K$. noctiflora Nopporncharoenkul \& Jenjitt ${ }^{21}$ for Thailand flora, K. xiengkhouangensis Picheans. \& Phokham from Lao $\mathrm{PDR}^{18}$. In 2019, two new more Kaempferia species namely K. phuphanensis Saensouk \& P.
Saensouk $^{22}$ and $K$. mahasarakhamensis Saensouk \& P. Saensouk ${ }^{23}$ were discovered by Saensouk \& Saensouk for Thailand flora. Two species $K$. parviflora and $K$. daklaknensis were both newly recorded as species for Vietnam flora ${ }^{24}$. These results indicate the biodiversity of Zingiberaceae species in general and Kaempferia species in particular is quite abundant and South East Asia is a center of Kaempferia biodiversity.

The morphological characteristics of Kaempferia species were described in details in several publications. $K$. galanga is differentiated from other galangals by the absence of stem and dark brown, rounded rhizomes, while the other varieties all have stems and pale rose-brown rhizomes. $K$. parviflora is a perennial herb that grows to $90 \mathrm{~cm}$ height with dark purple to black rhizomes ${ }^{13}$. K. pulchra was diffentiated from $K$. elegans by analysis of molecular phylogenetic and morphological evidences ${ }^{25}$. Kaempferia pandurata is a synonym of Boesenbergia rotunda (L.) Mansf., no morphological properties but chemical compositions of this species is mentioned in this review. Moreover, the morphological characteristics of several most abundant and important Kaempferia species are listed in the Table 2S (Supporting Information) which is useful for professional botanist as well as scientists of 
other natural branches for their research.

\subsection{Phytochemical study}

The Kaempferia species of Zingiberaceae family are used as herbal plants for treatment of various ailments so that their chemical compositions are highly interested. Research on chemical composition of Kaempferia plants revealed natural compounds classified in monoterpenoids, diterpenoids, flavonoids, phenolic glycosides, cyclohexane oxide derivatives, diarylheptanoids and essential oil with various biological properties.

\subsubsection{Monoterpenoids / Diterpenoids}

Diterpenoids seem to be the most abundant constituents in Kaempferia species with many publications related to these compounds ${ }^{25}$.

According to Emerenciano, there are 12 different skeletal structures classified for diterpenoids. At time of writing this review, 74 diterpenoids of skeletal types including labdane, clerodane, pimarane / isopimarane, abietane, and oxygenated isopimaranes-type diterpenoids are found in Kaempferia species $^{26}$ (Table 2).<smiles>C=C1CCCC2(C)C1CCC(=C)C2CC1(C)C=C(C)CC1=O</smiles>

propadane A (1)<smiles>C=C1CC[C@H]2C(C)CCCCC2(C)C1CC(O)CCO</smiles>

propadane B (2)<smiles>C=CC1CC(O)C2CCC3C(C)=CCCC3C12C(=O)O</smiles>

propadane C (3)<smiles>C=CC1(O)CCC2C(CCC3C(=C)C=CCC32)C1</smiles>

cleroda-2,4(18),14trien-13-ol (4)<smiles>C[C@H]1CCC[C@]2(C)[C@@H]3CC/C(=C/C(=O)O)C=C3CC[C@H]12</smiles><smiles>C=C1CCC2C(C)CCCC2(C)C1CCc1ccoc1</smiles>

Anticopalic acid (5)

(+)-15,16-Epoxy-8(17), 13(16), 14-labdatriene (6)<smiles>C=C1CCC2C(C)(C)CCC[C@]2(C)[C@H]1CC/C(C)=C/C(C)=O</smiles>

(+)-Pumiloxide (7) Methyl anticopalate (8)<smiles>C=C1CC[C@H]2[C@@H](C)CCC[C@]2(C)[C@H]1CCC(C)=O</smiles><smiles>CC1(C)CCC[C@@]2(C)C1CCC1=C/C(=C\CO)CC[C@@H]12</smiles><smiles>C=C1CCC2C(C)(C)CCC[C@]2(C)[C@H]1CC[C@H](C)CCO</smiles><smiles>C=C1CCC2[C@H](C)CCC[C@H]2[C@H]1CCC1=CC(=O)OC1</smiles>

13-Oxo-14,15-bis-norlabd-8(17)-ene (9)

Anticopalol (10)

8(17)-Labden-15-ol (11)

Labda-8(17),13(14)diene-15,16-olide (12)<smiles>CC1CCCC2C3=CC=C(CO)CCC3C12C</smiles>

Labda-8(17),13(Z)diene-15,16-diol (13)<smiles>C=C1CCC2C(C)(C)CCC[C@]2(C)[C@H]1C/C=C(/C=O)CC(OC)OC</smiles>

Calcaratarin A (14)

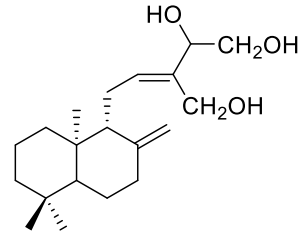

labda-8(17),12-dien-14,15,16-triol (14a)<smiles>C=C[C@](C)(O)CC[C@H]1[C@H](C)CC[C@H]2C(C)=CCC[C@H]12</smiles>

(-)-Kolavelool (15)

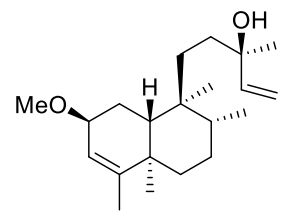

Dysoxydensin E (16)

Figure 1. Chemical structures of chemical compositions of Kaempferia species. 
<smiles>C=C[C@](C)(O)CC[C@H]1[C@H](C)CC[C@@]2(C)C(C)=CC(=O)C[C@H]12</smiles><smiles>C=C[C@](C)(O)CC[C@H]1[C@H](C)CC[C@H]2C(C)=C[C@@H](O)C[C@H]12</smiles><smiles>C=C[C@]1(C)CC[C@H]2C3C[C@H](O)C=C(C)[C@@]3(C)CC[C@@H]2C1</smiles>

13-epi-roseostachenone (17) (-)-2ß-Hydroxykolavelool (18) (+)-13-epi-2 $\alpha$-hydroxykolavelool (19)<smiles>C=C[C@]1(C)C=C(CC(O)C2[C@H](C)C(=O)CC[C@H]2C)C(=O)CC1</smiles>

Kaemgalangol A (20)<smiles>[R]C1C2=C[C@@](C)(C=C)CC[C@H]2[C@@]2(C)CCCC(C)(C)[C@H]1C2[R]</smiles>

$\mathrm{R}=\mathrm{H} ; \mathrm{R}_{1}=\mathrm{OH}$ Boesenberol I (21) $\mathrm{R}=\mathrm{OH} ; \mathrm{R}_{1}=\mathrm{H}$ Boesenberol $\mathrm{J}$ (22)<smiles>C=CC1(C)CCC2=C(C[C@H](O)[C@H]3C(C)(C)CC[C@@H](O)[C@@]23C)C1=O</smiles>

Boesenberol A (23)

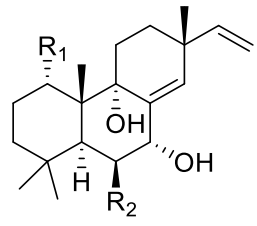

$\mathrm{R}_{1}=\mathrm{OH}, \mathrm{R}_{2}=\mathrm{H}$ Boesenberol $\mathrm{B}(24)$

$\mathrm{R}_{1}=\mathrm{OH}, \mathrm{R}_{2}=\mathrm{OAc}$ Boesenberol C (25)

$\mathrm{R}_{1}=\mathrm{H}, \mathrm{R}_{2}=$ OAc Boesenberol D (26)<smiles>C=CC1(C)C=C2C(O)C[C@H]3C(C)(C)CCC[C@]3(C)[C@]2(O)[C@H](O)C1</smiles>

Boesenberol E (27)

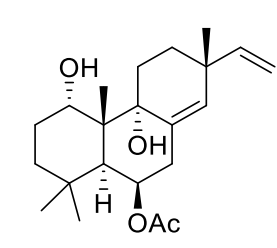
Boesenberol H (30) Boesenberol K (31) $\begin{gathered}6 \beta \text {-acetoxysandaraco } \\ \text { pimaradiene- } 1 \alpha, 9 \alpha \text {-diol (32) }\end{gathered}$

$\mathrm{R}=\mathrm{H}$ Boesenberol $\mathrm{F}(\mathbf{2 8})$ $\mathrm{R}=$ Me Boesenberol $\mathrm{G}(\mathbf{2 9})$<smiles>C=CC1(C)CCC2=C([C@H](OC)[C@@H](O)[C@@H]3C(C)(C)CCC[C@]23C)[C@@H]1OC</smiles><smiles>C=C[C@]1(C)C=C2[C@@H](O)[C@H](O)C3C(C)(C)CCC[C@]3(C)[C@H]2[C@H](O)C1</smiles>

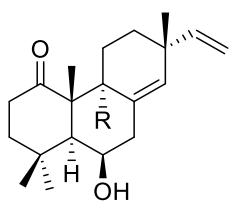

$\mathrm{R}=\mathrm{H}$ 6ß-hydroxypimara-8(14),15-diene-1-one (38)

$\mathrm{R}=\mathrm{R}_{1}=\mathrm{R}_{2}=\mathrm{R}_{3}=\mathrm{R}_{4}=\mathrm{H}$ (-)-sandaracopimaradiene (33)

$\mathrm{R}=\mathrm{OH}$ sandaracopimaradien- $6 \beta, 9 \alpha$-diol-I-one (39) $\mathrm{R}=\mathrm{OH} ; \mathrm{R}_{1}=\mathrm{R}_{2}=\mathrm{R}_{3}=\mathrm{R}_{4}=\mathrm{H}$ sandaracopimaradiene- $9 \alpha-\mathrm{ol}$ (34) $\mathrm{R}=\mathrm{R}_{2}=\mathrm{OH} ; \mathrm{R}_{1}=\mathrm{R}_{3}=\mathrm{R}_{4}=\mathrm{H}$ 8(14),15-sanderacopimaradiene-1 $\alpha, 9 \alpha$-diol (35)

$\mathrm{R}=\mathrm{R}_{1}=\mathrm{R}_{4}=\mathrm{H} ; \mathrm{R}_{2}=\mathrm{OH} ; \mathrm{R}_{3}=\mathrm{OAc} 2 \alpha$-acetoxysandaracopimaradien- $1 \alpha$-ol (36)

$\mathrm{R}=\mathrm{R}_{1}=\mathrm{R}_{3}=\mathrm{H} ; \mathrm{R}_{2}=\mathrm{R}_{4}=\mathrm{OH}$ 1,11-dihydroxypimara-8(14),15-diene (37)

$\mathrm{R}=\mathrm{R}_{1}=\mathrm{R}_{3}=\mathrm{R}_{4}=\mathrm{H} ; \mathrm{R}_{2}=\mathrm{OH}$ kaempulchraol I (40)

$\mathrm{R}=\mathrm{R}_{3}=\mathrm{R}_{4}=\mathrm{H} ; 2 \mathrm{R}_{1}=\mathrm{R}_{2}=\mathrm{OH}$ kaempulchraol $\mathrm{E}$ (41)

$\mathrm{R}=\mathrm{OH}, \mathrm{R}_{1}=\beta-\mathrm{OAc}, \mathrm{R}_{2}=\mathrm{R}_{3}=\mathrm{R}_{4}=\mathrm{H}$ kaempulchraol $\mathrm{K}(43)$

$\mathrm{R}=\mathrm{OMe} ; \mathrm{R}_{1}=\mathrm{OH} ; \mathrm{R}_{2}=\mathrm{R}_{3}=\mathrm{R}_{4}=\mathrm{H}$ kaempulchraol $\mathrm{L}$ (44)

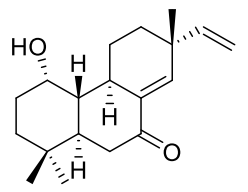

$\mathrm{R}=\mathrm{R}_{2}=\mathrm{R}_{3}=\mathrm{OH}, \mathrm{R}_{1}=\mathrm{R}_{4}=\mathrm{H}$ kaempulchraol $\mathrm{M}(\mathbf{4 5})$

Kaempulchraol J (42)

$\mathrm{R}_{2}=\mathrm{R}_{3}=\mathrm{R}_{4}=\mathrm{OH}, \mathrm{R}=\mathrm{R}_{1}=\mathrm{H}$ 1,2,11-trihydroxy-14b-methoxypimara-8(14),15-diene (48)

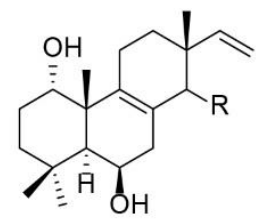

$\mathrm{R}=\alpha-\mathrm{OH}$ kaempulchraol $\mathrm{N}(46)$

$\mathrm{R}=\beta$-OMe kaempulchraol O (47)

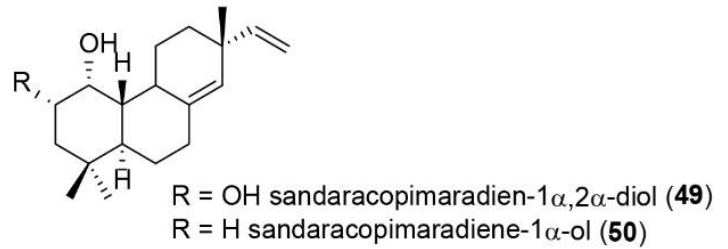

$\mathrm{R}=\mathrm{H}$ sandaracopimaradiene- $1 \alpha-\mathrm{ol}(\mathbf{5 0})$

Figure 1. Chemical structures of chemical compositions of Kaempferia species. (cont.) 


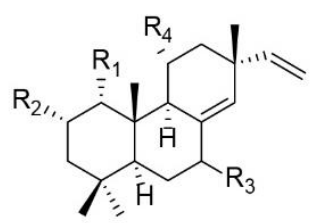

$\mathrm{R}_{1}=\mathrm{R}_{2}=\mathrm{OH}, \mathrm{R}_{3}=\mathrm{O}, \mathrm{R}_{4}=\mathrm{H}$ 1,2-dihydroxypimara-8(14),15diene-7-one (51) $\mathrm{R}_{1}=\mathrm{R}_{2}=\mathrm{OH}, \mathrm{R}_{3}=\beta-\mathrm{OH}, \mathrm{R}_{4}=\mathrm{H}$ 1,2,7-trihydroxy-pimara-8(14),15-dience (52) $\mathrm{R}_{1}=\mathrm{R}_{2}=\mathrm{R}_{4}=\mathrm{OH}, \mathrm{R}_{3}=\mathrm{H} 1,2,11$-trihydroxy-pimara-8(14),15-diene (53) $\mathrm{R}_{1}=\mathrm{R}_{4}=\mathrm{OH}, \mathrm{R}_{3}=\alpha_{-} \mathrm{OH}, \mathrm{R}_{2}=\mathrm{H} 1,7,11$-trihydroxy-pimara-8(14),15-diene (54) $\mathrm{R}_{1}=\mathrm{R}_{4}=\mathrm{OH}, \mathrm{R}_{2}=\mathrm{R}_{3}=\mathrm{H}$-1,11-dihydroxypimara-8(14),15-diene (55)<smiles>CC(C)C1=CC2CC[C@H]3[C@@H](C)CCCC[C@]3(C)[C@H](O)CC2C1</smiles>

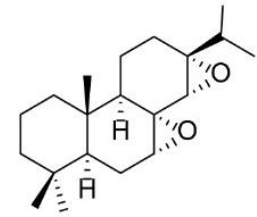

roscotane $C(58)$

roscotane D (59)<smiles>[R]C1CC2C(C)(C)CCC[C@]2(C)c2ccc(C(C)C)cc21</smiles>

$\mathrm{R}=\mathrm{H}$ ar-abietatriene $(60)$

$\mathrm{R}=\mathrm{O}$ 7-dehydroabietanone (61)

$\mathrm{R}=\mathrm{a}-\mathrm{OH}$ abieta-8,11,13-trien-7a-ol (62)<smiles>[R]C1CCC(C)(C)[C@H]2CCC3=C[C@](C)(C=C)CC[C@H]3[C@]12C</smiles>

$\mathrm{R}=\mathrm{H}$ (-)isopimara-8(14),15-diene (67) $\mathrm{R}=\mathrm{OH} 1 \alpha$-hydroxyisopimara-8(14),15-diene (68)<smiles>C=C[C@]1(C)CCC2=C(C1)C(=O)C[C@H]1C(C)(C)CCC[C@]21C</smiles>

isopimara-8,15-diene-7-one $\mathbf{( 7 1 )}$<smiles>C[C@H]1CCC[C@@]2(C)C3=C(CC[C@H]12)[C@H](CO)[C@H](C)[C@H]3C</smiles>

roscorane $\mathrm{A}(63)$

$\mathrm{R}=\mathrm{OH}, \mathrm{R}_{1}=\mathrm{R}_{2}=\mathrm{R}_{4}=\mathrm{H}, \mathrm{R}_{3}=\mathrm{OH}$ roscorane $\mathrm{B}$ (64) $\mathrm{R}=\mathrm{R}_{4}=\mathrm{H}, \mathrm{R}_{1}=\mathrm{R}_{2}=\mathrm{R}_{3}=\mathrm{OH}$ roscorane $\mathrm{C}(\mathbf{6 5})$ $\mathrm{R}=\mathrm{R}_{2}=\mathrm{R}_{3}=\mathrm{H}, \mathrm{R}_{1}=\mathrm{R}_{4}=\mathrm{OH}$ roscorane $\mathrm{D}(\mathbf{6 6})$<smiles>[R]C1C[C@H]2C(C)(C)CCC[C@]2(C)[C@H]2CC[C@](C)(C=C)C=C12</smiles>

$\mathrm{R}=\mathrm{O}$ isopimara-8(14),15-diene-7-one (69) $\mathrm{R}=\alpha-\mathrm{OH}$ 7a-hydroxyisopimara-8(14),15-diene (71)<smiles>[R]C(=O)/C=C/c1ccc([R])cc1</smiles>

$\mathrm{R}_{1}=-\mathrm{OEt}, \mathrm{R}_{2}=\mathrm{H}$ Ethyl trans-p-methoxy cinnamate (72) $\mathrm{R}_{1}=-\mathrm{OEt}, \mathrm{R}_{2}=\mathrm{H}$ Ethyl cinnamate (73) $\mathrm{R}_{1}=-\mathrm{OH}, \mathrm{R}_{2}=\mathrm{OMe} \mathrm{p}-$ Methoxycinnamic acid (74)<smiles>CC1(C)C=Cc2c(cc(O)c3c(=O)cc(-c4ccccc4)oc23)O1</smiles>

2",2"-Dimethylpyrano-[5",6":8,7]-flavone (75)<smiles>COc1cc(O)c(C(=O)/C=C/c2ccccc2)c2c1C=CC(C)(CCC=C(C)C)O2</smiles>

Boesenbergin A (76)

Figure 1. Chemical structures of chemical compositions of Kaempferia species. (cont.) 
<smiles>[R7]O[R]O[R]([R])=O</smiles>

$\mathrm{R}_{1,2}=\mathrm{OH}$ pinocembrin (86)<smiles>[R7]OC1(O)Oc2cc(O)cc(O)c2[C@@H]1c1ccc(OC)c(O)c1</smiles><smiles>[R]O[C@]12Oc3cc(O)cc(O)c3[C@H]1c1cc(O)c(OC)cc1C2=O</smiles>

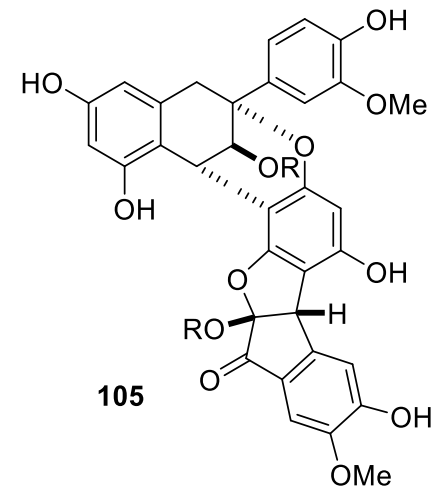

$$
R=\text { L-Rha-(1-6) }- \text { D-Glc }
$$

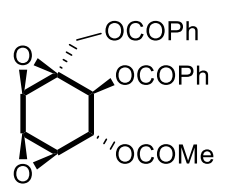

crotepoxide (115)

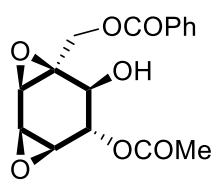

(-)-(1R,2R,4R,5S,6R,7R)- 4Benzoyloxymethyl-3,8- 24 dioxa tricyclo[5.1.0.0 $\left.0^{2,4}\right]$ octane-5,6-diol 6-acetate (118)

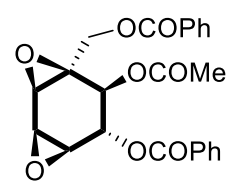

boesenboxide (116)

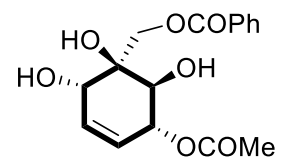

(-) zeylennol (117)

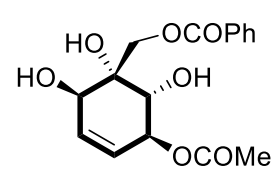

(+)-zeyleno (117a)I

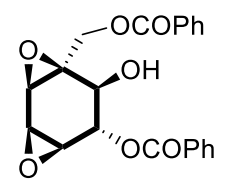

(-)-(1R,2R,4R,5S,6R,7R)-4Benzoyloxymethyl- 3,8- dioxa tricyclo[5,1,0,0,4] -octane- 5,6-diol 6-benzoate (120)

Figure 1. Chemical structures of chemical compositions of Kaempferia species. (cont.) 


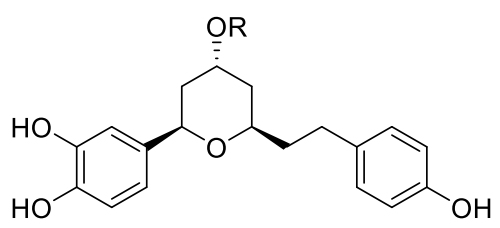

$\mathrm{R}=\mathrm{H}$ 1,5-epoxy-3-hydroxy-1-(3,4-dihydroxyphenyl)-7-(4-hydroxyphenyl) heptane (122) $\mathrm{R}=\mathrm{Glc} 3-\mathrm{O}-\beta-\mathrm{D}$ - glucopyranoside of $(122)(123)$<smiles>Oc1ccc(CC[C@@H](O)C[C@@H](O)CCc2ccc(O)c(O)c2)cc1</smiles>

3,5-di-hydroxy-1-(3,4-dihydroxyphenyl)-7-(4hydroxyphenyl)heptane (121)<smiles>COc1cc(C(O)C(O)C(O)CC(O)C(O)Cc2ccc(O)cc2)ccc1O</smiles>

galanheptanoxide (124)

Figure 1. Chemical structures of chemical compositions of Kaempferia species. (cont.)

Typically, twenty diterpenoids (abietanetype and isopimarane-type skeleton), including four oxygenated abietanes (roscotanes A-D, (56-59)), four oxygenated pimaranes (roscoranes A-D (63-66)), along with twelve known diterpenoids (labdanes) were isolated from the whole plants of $K$. roscoeana collected from Phetchaburi Province, Thailand by Boonsombat et al. ${ }^{6}$ Swapana et al. isolated a labdane with unusual 9,10seco-isopimarane skeleton namely kaemgalangol A(20) and 12 usual analogs (2-13) from the rhizomes of K. galanga collected from Imphal West and Senapati district, Manipur, a state in North East India ${ }^{1}$. Isopimarane diterpenes namely boesenberols I-K (2131) were also isolated from $K$. pandurata rhizomes collected from Khon Kaen, Thailand ${ }^{27}$, seven new isopimarane diterpenoids namely kaempulchraols I-O (40-47), together with one known analog ${ }^{28}$ from the $\mathrm{CHCl}_{3}$ soluble extract of $K$. pulchra rhizomes collected

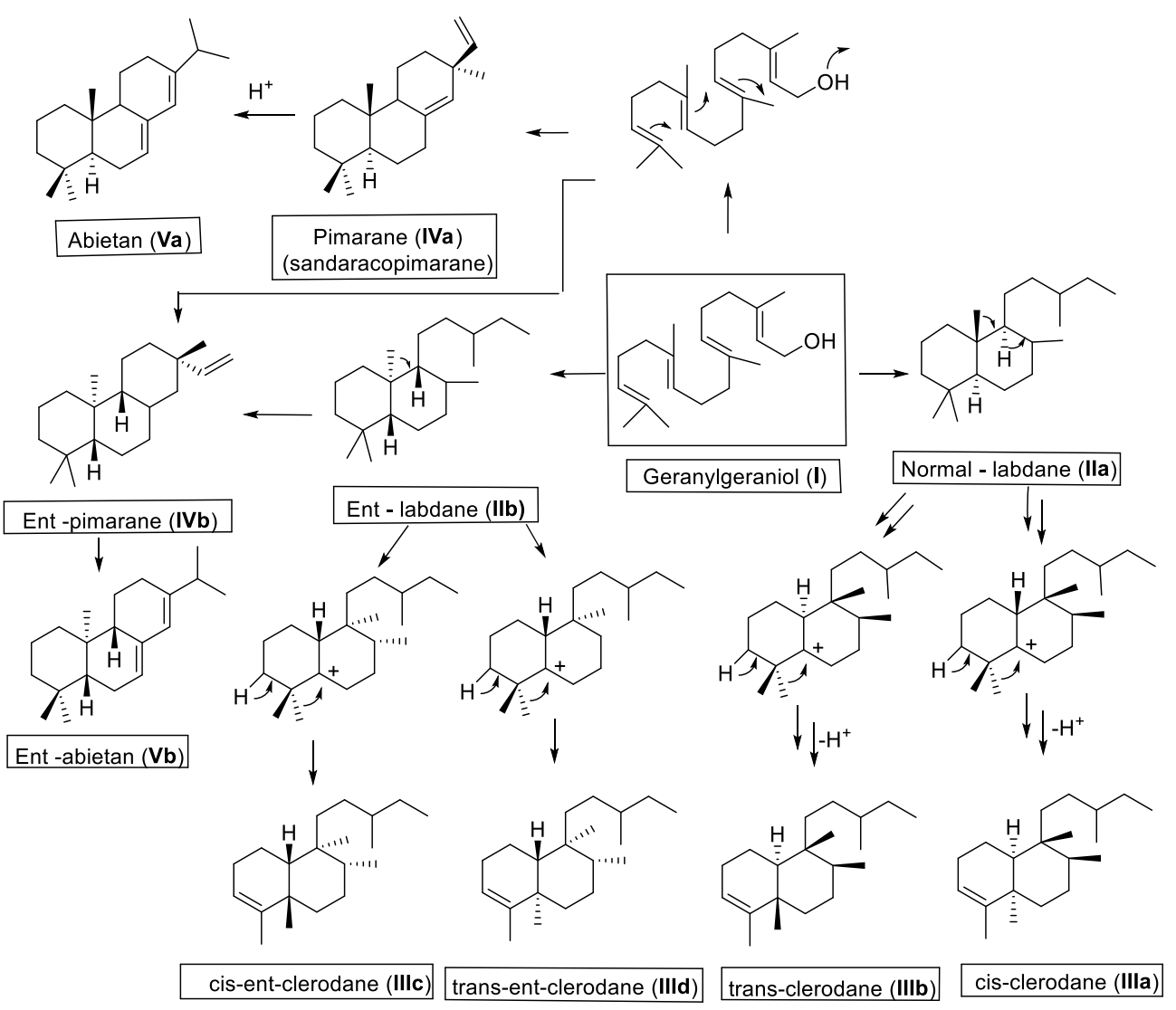

Figure 2. Biogenesis of diterpenoid skeletons from geranylgeraniol (I). 


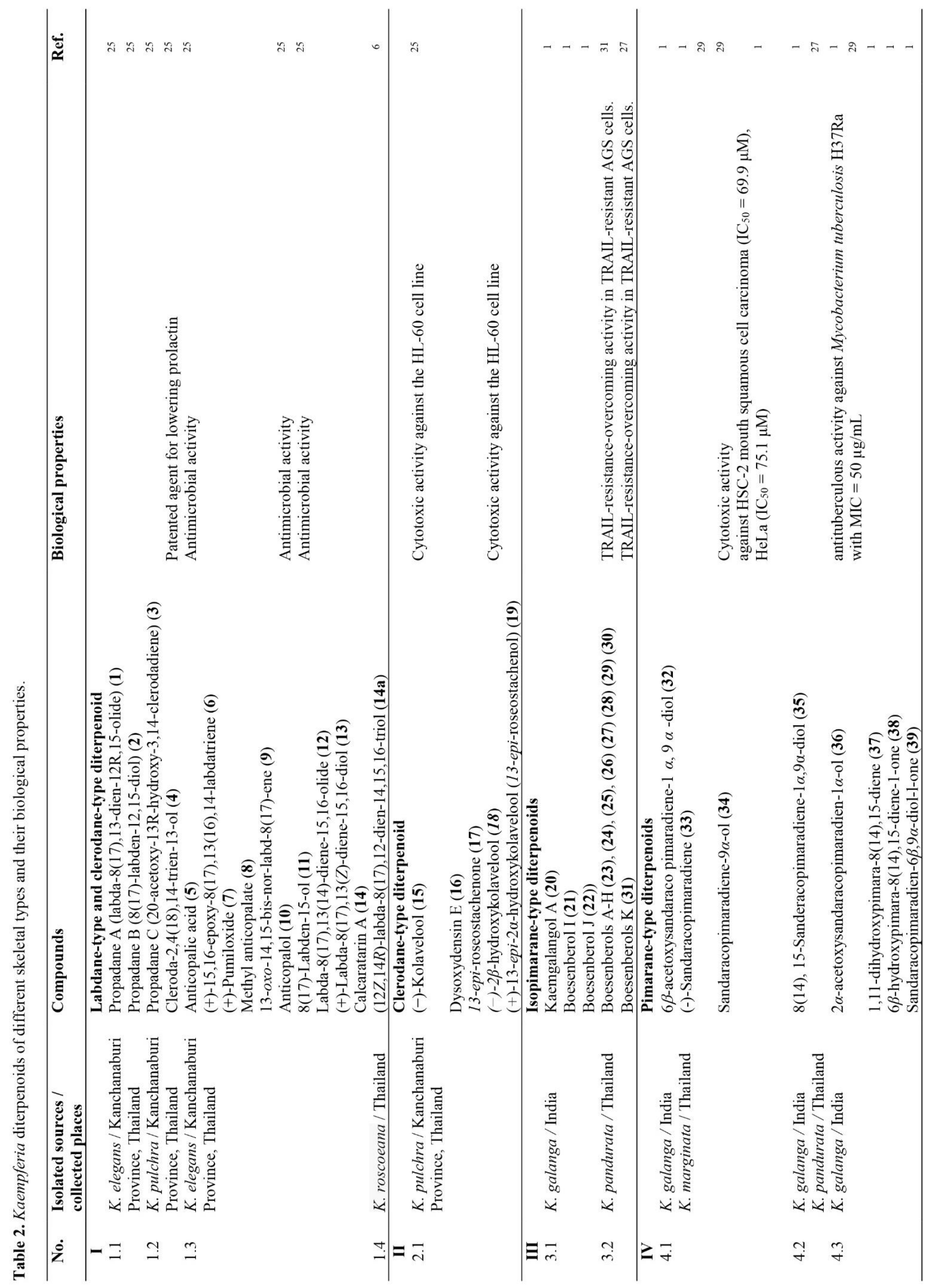


Pharmaceutical Sciences Asia

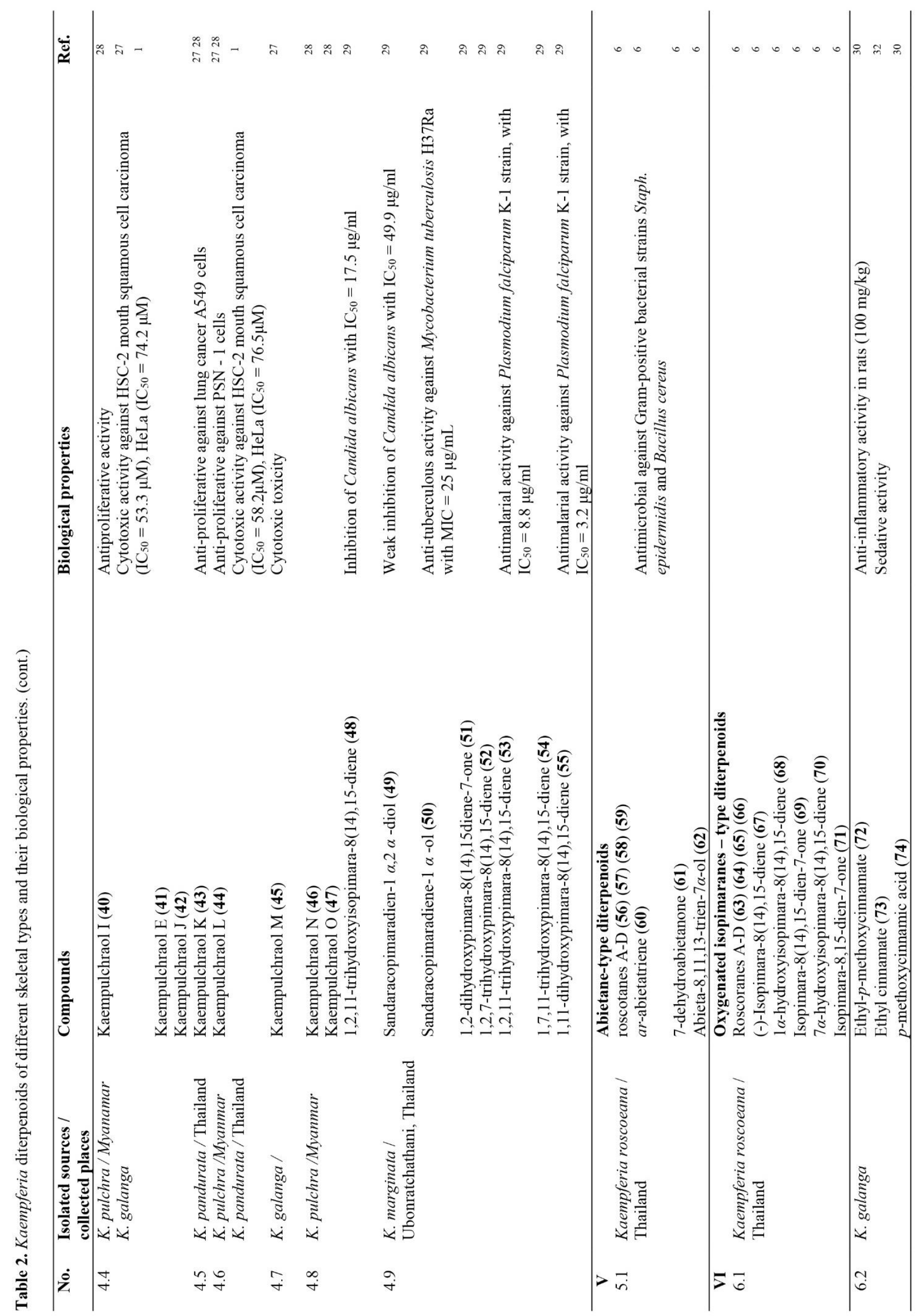


from Pindaya Township, Shan State, Myanmar. Thongnest et al. isolated six new pimarane-type diterpenoids along with four known diterpenes from the dichloromethane extract of whole plants of $K$. marginata collected in Ubonratchathani, Thailand ${ }^{29}$. Monoterpenes such as cinnamate derivatives including ethyl$p$-methoxycinnamate (72), ethyl cinnamate (73) and $p$-methoxycinnamic acid (74) were found in K. galanga roots ${ }^{30}$. The Kaempferia diterpenoids with their biological properties, which we discussed in following section, were presented in Table 2 and their structures were displayed in Figure 1.

\subsubsection{Diterpenoid biogenesis}

Diterpene skeleton is produced from geranylgeraniol $(\mathbf{I})\left(\mathrm{C}_{20} \mathrm{H}_{34} \mathrm{O}\right)$ which rearranges along one of two routes, to labdane (normal (IIa) or ent - labdane (IIb)). Normal-labdane (IIa) rearranges multistep in the presence of protone to cis-clerodane (IIIa) and trans-clerodane (IIIb) while ent-labdane (IIb) repositions to cis-ent-clerodane (IIIc) and trans-entclerodane (IIId). The relocation of $\square$-bonds and the rearrangement of proton or methyl group in geranylgeraniol (I) also lead to pimarane (IVa) (sandaracopimarane (35)) and ent-pimarane (IVb) (isopimarane), whose rearrangements lead to abietane $(\mathbf{V a})$ and entabietane (Vb) respectively (Figure 2) ${ }^{33}$. Another route, as suggestion from Swapana et. al., the biogenesis pathway of abietane diterpenoids like roscorane A (5) could be derived from sandaracopimaradiene $(\mathbf{3 3})^{1,6}$, where the double bond in (33) was epoxidized and protonated and rearranged to be a primary cyclic alcohol roscorane A (63) (Figure 3).

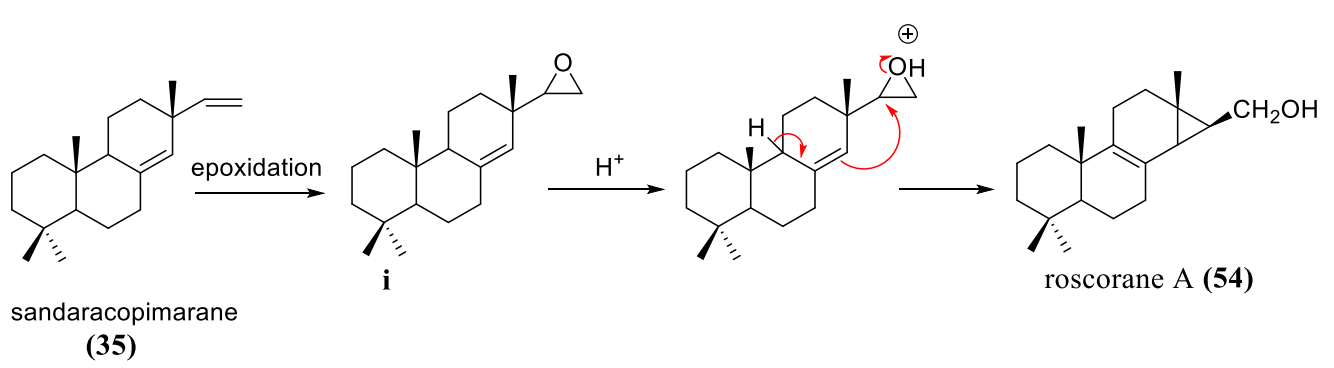

Figure 3. Biogenesis Pathways of an abietane compound - roscorane A (5) from pimarane skeleton - sandaracopimarane.

\subsubsection{Flavonoids}

Several flavones were separated from $K$. elegans, $K$. pandurata and $K$. rotunda. Flavonoids like cardamonin (75) pinostrobin (76) alpinetin (77), pinocembrin (78) were isolated from K. pandurata $^{34}$. 2",2"-dimethylpyrano-[5",6":8,7]flavone (79) was isolated from $K$. elegans ${ }^{25}$. Chalcons and derivatives like panduratin A-C (80) (81) (82), hydropanduratin $\mathrm{A}(\mathbf{8 3})$ and boesenbergin A - B (84) (85) were also isolated from K. pandurata ${ }^{35,36}$. Flavonoids especially polymethoxy flavonoid (PMF) are secondly abundant compounds found in Kaempferia. PMF were isolated from Kaempferia species were listed in Table 3.

Highly-methoxy flavones were isolated mainly from $K$. parviflora and $K$. pandurata. Saewong et. al. by using silica gel column chromatography and HPLC separated and identified 12 known methoxyflavonoids from the chloroform fraction and ethanol extract of $K$. parviflora rhizomes including techtochrysin (86, $0.131 \%$ yield from the material), 5,7-dimethoxyflavone $(\mathbf{8 7}, 0.289 \%), \quad 7,4^{\prime}$ dimethylapigenin $(\mathbf{8 8}, 0.0453 \%)$, trimethylapigenin
(89, 1.29\%), 5-hydroxy-3,7-dimethoxyflavone (90, $0.0252 \%), 3,5,7$-trimethoxyflavone (91, 0.0101\%), $3,7,4^{\prime}$-trimethylkaempferol $\quad(\mathbf{9 2}, \quad 0.0719 \%)$, tetramethylluteolin $\mathbf{( 9 3}, 0.0312 \%), 3,5,7,4$ ' tetramethylkaempferol $(\mathbf{9 4}, 0.0070 \%)$, retusine $\mathbf{( 9 5}$, $0.0215 \%)$, ayanin $(\mathbf{9 6}, 0.0111 \%)$ and pentamethylquercetin $(\mathbf{9 7}, 0.391 \%)^{43}$. The same methoxyflavonoids were also isolated from the black rhizomes of $K$. pandurata ${ }^{38}$. In other publication, they also reported to isolate some other methoxyflavonoids ${ }^{13}$ which were listed in Table 3 .

Panduratin A (78) and its derivatives panduratin B-C (79) (80) are a chalcone derivative isolated from the rhizome of $K$. pandurate has various biological activities including anti-proliferative and apotosis-induced effect in human colon cancer cells, antiinflammatory actions by inhibition of NO production in RAW 264.7 cells, anti-human immunodeficiency virus-1 protease activity, protective skin ageing induced by ultraviolet radiation, and anti-bacterial activity ${ }^{44}$. Panduratin A (78) and its pharmacological effect is mentioned in several patents described later in this review. 


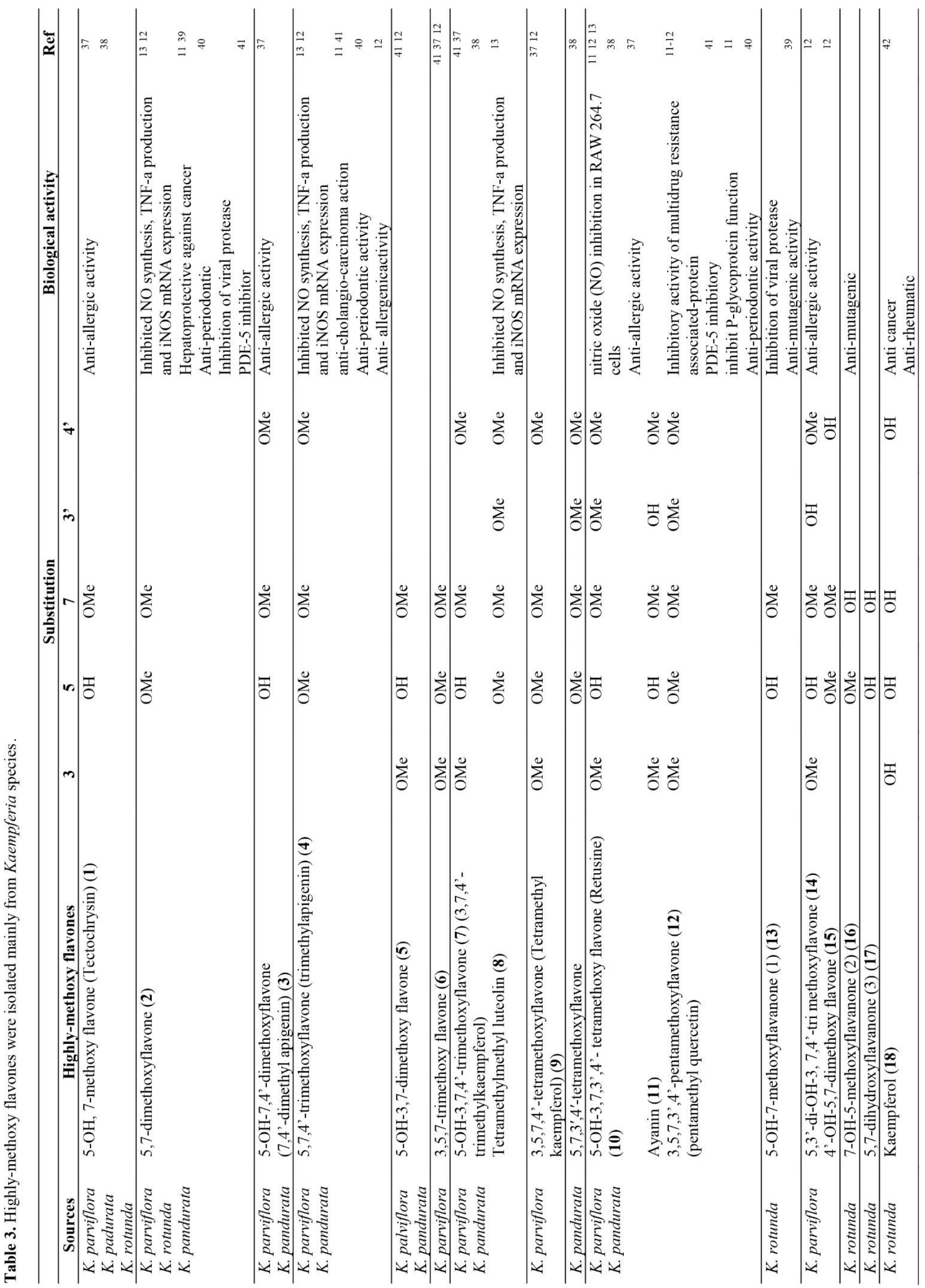




\subsubsection{Phenolic glycosides}

Several flavonol glycosides were isolated from the water soluble fraction of rhizomes of Kaempferia parviflora including rel$(5 \mathrm{a} S, 10 \mathrm{~b} S)-5 \mathrm{a}, 10 \mathrm{~b}$-dihydro-1,3,5a,9tetrahydroxy8-methoxy-6H-benz[ $b]$ indeno[1,2- $d]$ furan-6-one $5 \mathrm{a}-\mathrm{O}$ [ $\alpha$-L-rhamnopyranosyl-( $1 \rightarrow 6)-\beta$-D-glucopyranoside] (104), its rel-5aS, $10 \mathrm{~b} R$ isomer (105), and $(2 R, 3 S, 4 S)-3-O$ - $[\alpha$-L-rhamnopyranosyl- $(1 \rightarrow 6)-\beta$-Dglucopyranosyl]-3'-O-methyl-ent-epicatechin- $(2 \alpha \rightarrow$ $O \rightarrow 3,4 \alpha \rightarrow 4)-(5 \mathrm{a} S, 10 \mathrm{~b} S)-5 \mathrm{a}, 10 \mathrm{~b}-d i h y d r o-1,3,5 \mathrm{a}, 9-$ tetrahydroxy-8-methoxy- $6 H$-benz $[b]$ indeno $[1,2-d]$ furan-6-one $5 \mathrm{a}-O-[\alpha$-L-rhamnopyranosyl- $(1 \rightarrow 6)-\beta$ D-glucopyranoside] $(\mathbf{1 0 6})^{45}$.

\subsubsection{Fatty acids and derivatives}

According to Ali et. al., the rhizome of $K$. galanga $\mathrm{L}$. collected from the hilly areas of Chittagong, Bangladesh were extracted with methanol to obtain methanolic crude extract. GC-MS analysis of this extract showed the presence of fatty acids and derivatives including palmitic acid (35.17\%) (107), oleic acid $(22.15 \%)(\mathbf{1 0 8})$, octadecanoic acid $(10.10 \%)$ (109), phthalic acid (110), glycidyl stearate (7.27\%) (111), 2-Propenoic acid (112), 3-(4methoxyphenyl)-, ethyl ester (10.18\%) (113), 6ethyloct-3-yl2-ethylhexyl ester (3.37\%) (114), sandaracopimaradiene (8.20\%) (33), and 2-[2-(4nonylphenoxy)ethoxy]ethanol (3.57\%) (115) ${ }^{7}$.

\subsubsection{Cyclohexane diepoxide derivatives}

A series of cyclohexane diepoxides and cyclohexane oxide derivatives were isolated from the fresh rhizomes of $K$. angustifolia collected in Thailand including crotepoxide (116) and boesenboxide (117), (-)-Zeylenol (118), (-)-(1R,2R,4R,5S,6R,7R) - 4 - benzoyloxymethyl3,8 - 24 dioxatricyclo $\left[5,1,0,0^{2,4}\right]$ octane-5,6diol 6-acetate (119), (-)-(1R,2R,4R,5S,6R,7R) -4-benzoyloxymethyl- 3,8- dioxatricyclo $\left[5,1,0,0^{2,4}\right]$-octane - 5,6 - diol 6-benzoate (120), and $(+)$-zeylenol $(\mathbf{1 2 1})^{46}$.

\subsubsection{Diarylheptanoids}

Several diarylheptanoids including (3R,5S)-3,5-di-hydroxy-1-(3,4-dihydroxyphenyl) -7-(4-hydroxyphenyl)heptane (122), (1R,3R,5R)1,5-epoxy-3-hydroxy-1-(3,4-dihydroxyphenyl)7-(3,4-dihydroxyphenyl) heptane (123), with its glycoside (1R,3R,5R)-1,5-epoxy-3-hydroxyl-1(3,4-dihydroxyphenyl)-7-(4-hydroxyphenyl)heptane 3-O- $\beta$-D-glucopyranoside (124), and 1-(4-hydroxy3-methoxyphenyl)-7-(4-hydroxyphenyl)heptane1,2,3,5,6-pentaol (namely galanheptanoxide) (125) were isolated from the $K$. galanga rhizome collected in Guangzhou, China ${ }^{47}$. These isolated diarylheptanoids exhibited pronounced inhibitory activities compared with indomethacin on NO production induced by LPS in RAW 264.7 with the most effective $\mathrm{IC}_{50}=26.98 \pm 1.39 \mu \mathrm{M}$ of compound (3R,5S)-3,5-di-hydroxy1-(3,4-dihydroxyphenyl)7-(4-hydroxyphenyl) heptane (122).

\subsubsection{Essential oils}

According to Ridtidid et. al., the major chemical constituents of the essential oil extracted from dried $K$. galanga rhizome were ethyl-p-methoxycinnamate $(31.77 \%) \quad$ (72), methyl cinnamate $(23.23 \%)$ (126), carvone (11.13\%) (127), eucalyptol (9.59\%) (128) and pentadecane $(6.41 \%)(\mathbf{1 2 9})$, respectively ${ }^{48}$. Wong et. al. reported that the hat the composition of the essential oil of rhizomes of $K$. galangal L. contained 54 components $^{3,49}$, of which the major constituents are ethyl-trans- $p$-methoxy cinnamate $(16.5 \%)$ (72), pentadecane $(9 \%)$ (130), 1,8 -cineole $(5.7 \%)$ (131), $\gamma$-carene $(3.3 \%)$ (132), borneole $(2.7 \%)$ (133) and other components in minor amount including camphene (134), kaempferol (102), kaempferide (135), cinnamaldehyde, $p$-methoxycinnamic acid (136) and ethyl cinnamate ${ }^{8}$. Other compounds as dicyclohexyl propanedinitrile (137), dipentene dioxide (138), 9-hydroxy, 2-nonanone (139), 2,7octadiene-1-yl acetate(140), ethyl cyclohexyl acetate (141), cis-11- tetradecenyl acetate (142), 2-heptadecanone (143), 4-methyl isopulegone (144), camphidine (145), trans,trans-octa-2, 4dieny acetate (146), 10 undecyn-1ol (147), 3,7dimethoxycoumarin (148), $\delta$-3-carene (149), alpha pinene (150), camphene (151), borneol (152), cymene (153), $\alpha$-terpineol (154), $\alpha$-gurjunene (155), germacrene (156), cadinene (157), caryophyllene (158), luteolin (159) and apigenin (160) were also present in the essential oil of this plant ${ }^{8,50}$. Terpene oil constituents made up to $16.4 \%{ }^{49}$.

\subsection{Biological properties}

The Kaempferia rhizome have also been reported to possess various biological activities including anti-microbial activities ${ }^{7}$, sedative and anti-nociceptive; cytotoxic; cancer-preventive, anti-tumor, anti-mutagenic, anti-proliferative; anti-rheumatic; anti-oxidant; anti-inflammatory; hepatoprotective; anti-allergic; antihypertensive, hypolipidemic ${ }^{30}$; anti-helmintic, anti-amoebic, mosquito repellent and larvicidal activities; vasorelaxant active and smooth muscle relaxant 
effects; aphrodisiac effects and wound healing activity, which are described in detail as following. Not only the rhizome extract, but also the constituents of Kaempferia species also possess various pharmacological activities. For instance, kaempferol (102) is a flavonoid commonly occurring in plants such as tea, beans and occurring widely in $K$. rotunda. Kaempferol was known to possess numerous biological activities including anticancer activity by inhibition of migration and invasion of several cancer cell lines ${ }^{42}$. PMFs with their multiplicity biological effects are reserved in various patents for their uses in life.

\subsubsection{Anti-microbial properties anti-fungal, anti-virus}

Boonsombat et. al. reported that, compound $a r$-abietatriene (60) isolated from the whole plants of $K$. roscoeana collected from Phetchaburi Province, Thailand, had a specific antimicrobial activity with the most activity against Gram-positive bacteria strains Staphylococcus epidermidis and Bacillus cereus with MIC (MBC) values of 25 (75) and 25 (50) $\mu \mathrm{g} / \mathrm{ml}$, respectively ${ }^{6}$. Other compounds as anticopalic acid (5), anticopalol (10), and 8(17)labden-15-ol (11) from $K$. elegans showed antimicrobial activity against the Gram-positive bacterium, Bacillus cereus, with MIC values of $3.13,6.25$, and $6.25 \mu \mathrm{g} / \mathrm{mL}$, respectively ${ }^{25}$.

Ethanol extract of $K$. pandurata showed powerful antibacterial activity against all the tested bacteria and was the most potent against MRCNS (methicillin-resistant coagulase negative Staphylococci) with MIC 4 ppm, Bacillus subtilis and MRSA (methicillin-resistant Staphylococcus aureus) with MIC 16 ppm, MSSA (methicillinsensitive Staphylococcus aureus) and Salmonella typhi with MIC $8 \mathrm{ppm}^{51}$. The chloroform extract, panduratin A (78) and isopanduratin A (78a) isolated from this plant extract also showed a good antibacterial activity by damage of bacterial cell wall and effects on bacterial virulence factors including protease enzyme and haemolysin against haemolysin against Streptococcus pyogenes $^{52,35}$. Essential oils of Zingiberaceae members in general and Kaempferia species in particular were known antimicrobial agents. The mode of antibacterial action of $K$. pandurata essential oil was its ability to change permeability of the cell, leakage the endocellular materials including inorganic compounds (potassium, calcium ion) and organic compounds (nucleic acid, protein) from cytoplasmic membrane and leading to death of $E$. coli $\mathrm{K} 1.1$ cell $^{53}$.

\subsubsection{Sedative and anti-nociceptive activity}

As mentioned in the Traditional Use session, Kaempferia species is special used in almost all folk medicines as pain killer on the whole body (abdominal, chest, headache, toothache, rheumatism, limb pains). Ridtitid et. al. investigated the biological activities of $K$. galanga and found that the methanol extract of this species exhibited anti-nociceptive activity. The mechanism of action is likely to be mediated peripherally and centrally (spinally and supraspinally), on opioid receptors on the nervous system ${ }^{48}$. Huang et. al. have found that, compounds ethyl trans-p-methoxycinnamate (72) and ethyl cinnamate (73) mainly active aromatic compounds of hexane extract of $K$. galanga collected in Japan caused sedative effects at dose of $0.0014 \mathrm{mg}$ and $0.0012 \mathrm{mg}$ by means on inhalation in mice ${ }^{32}$. This finding might be scientific evidence for the use of $K$. galanga in aromatherapy in treatment of some anxiety and psychological disorders in human ${ }^{32}$.

\subsubsection{Cytotoxic activity}

Compounds (-)-kolavelool (15) and (-)-2 $\beta$ hydroxykolavelool (18) from $K$. elegans showed selective cytotoxic activity against the HL-60 cell line with $\mathrm{IC}_{50}$ values of $8.97 \pm 0.66$ and $9.58 \pm 0.88 \mu \mathrm{g} / \mathrm{mL}$, respectively ${ }^{25}$. Swapana et. al. also reported that, diterpenoids, sandaracopimaradiene- $9 \alpha$-ol (34), kaempulchraol I (40) and kaempulchraol L (44) exhibited moderate activity against HSC-2 mouth squamous cell carcinoma with $\mathrm{IC}_{50} 69.9,53.3$ and $58.2 \mu \mathrm{M}$, respectively, more effective than against HeLa cells cervical cancer with $\mathrm{IC}_{50} 75.1,74.2$ and $76.5 \mu \mathrm{M}$, respectively ${ }^{1}$.

\subsubsection{Cancer-preventive, anti-tumor, anti- mutagenic and anti-proliferative activities}

The methanolic extract of $K$. galanga rhizome contained fatty acid like oleic acid (108), octadecanoic acid (109) and phthalic acid (110) found to induce apoptosis and also inhibited the cancer cell growth of Ehrlich ascites carcinoma (EAC) with $\mathrm{IC}_{50} 17.10 \mu \mathrm{g} / \mathrm{ml}^{7}$. Ethyl-pmethoxycinnamate markedly induced cytotoxicity on human oral squamous carcinoma HSC-3 ( IC $_{50} 0.075$ $\mathrm{mg} / \mathrm{mL}$ ) and $\mathrm{Ca} 922\left(\mathrm{IC}_{50} 0.085 \mathrm{mg} / \mathrm{mL}\right)$ cell lines ${ }^{54}$.

$K$. parviflora extract with $\mathrm{PMF}$ constituents like 3,5,7,3',4'-pentamethoxyflavone (97) and 5,7,3',4'-tetramethoxyflavone (94a) suppressed the weights of prostates and seminal vesicles in benign prostate hyperplasia (BPH) in rat model and can be applied as a promising natural medicine for the treatment of $\mathrm{BPH}^{55}$. 
One of the causing cancer factors is the DNA mutation ${ }^{39}$. This type of cancer is not only difficult to cure but also being general incidents leading to numerous deaths in the human population. Atun et. al. was evaluating the mutagenic inhibitory activity of natural compounds isolated from the methanol extract of K. rotund $a^{39}$. The anti-mutagenic activity test of three known flavanons was observed in vivo based on the number of micro-nucleated polychromatic cell erythrocytes (MNPCE) from male Balb-c mice (8-12 week) induced by a known immune system suppressor - cyclophosphamide. The results showed that \% anti-mutagenic activity of 7hydroxy-5-methoxyflavanone (101) dose $60 \mathrm{mg} / \mathrm{kg}$ BW and 5,7-dihydroxyflavanone (102) dose 60 $\mathrm{mg} / \mathrm{kg}$ BW (both followed cyclophosphamide 50 $\mathrm{mg} / \mathrm{kg}$ body weight) reached $100 \%$. While 5hydroxy-7-methoxyflavanone (98) dose $60 \mathrm{mg} / \mathrm{kg}$ body weight followed cyclophosphamide $50 \mathrm{mg} / \mathrm{kg}$ body weight demonstrated a $\%$ anti-mutagenic activity of $96.5 \%$. Meanwhile, at a dose of 60 $\mathrm{mg} / \mathrm{kg}$ body weight, three compounds showed a very high activity. Methanol extract of $K$. rotunda which is a crude extract contain a mixture of some flavanone compounds showed significant activity but lower than pure compounds ${ }^{39}$.

Win et. al. also reported that several diterpenoids kaempulchraol I-O (40-47) isolated from $K$. pulchra rhizomes (collected in Myanmar) were evaluated for their antiproliferative activity against human cancer cell lines ${ }^{28}$. Kaempulchraol I (40) exhibited mild antiproliferative activity against all of the cell lines including human lung cancer (A549); human cervix cancer (HeLa); human pancreatic cancer (PANC-1, PSN-1); human breast cancer (MDA-MB-231); and normal human primary fibroblast cell (TIG-3), with $\mathrm{IC}_{50}$ values ranging from 39.9 to $87.5 \mu \mathrm{M}$. Kaempulchraol $K(\mathbf{4 3})$ inhibited against lung cancer cell line A549 with $\mathrm{IC}_{50} 33.1 \mu \mathrm{M}$ (the anticancer drug 5-fluorouracil was used as a positive control with $\mathrm{IC}_{50} 2.8 \mu \mathrm{M}$ ). Kaempulchraol L (44) found in many Kaempferia species with the presence of the methoxy group at C-9, had a good antiproliferative activity against pancreatic cancer cell lines (PANC-1 and PSN-1) with $\mathrm{IC}_{50} 39.9$ and $22.6 \mu \mathrm{M}$ respectively.

In cancer chemotherapy, it is recognized that several cancer cell lines like lung, breast, prostate and gastric cancer have developed resistance to necrosis or apoptosis, which was induced by TNF-related ligand (Tumor necrosis factor-related apoptosis inducing ligand - TRAIL). The search of new anti-cancer agent from natural products sources based on the finding bioactive compounds with anti-TRAIL resistance activity is one of the research trend nowadays on anticancer drug discovery. Karmakar et. al. have found that $\mathrm{MeOH}$ extract of $K$. pandurate rhizomes and its all isolated compounds showed the TRAIL resistance overcoming activity against the human gastric adenocarcinoma (AGS) cells. Compound 6 $\beta$ acetoxysandaracopimaradiene- $1 \alpha, 9 \alpha$-diol (32) sensitized AGS cells to TRAIL-induced apoptosis by controlling the levels of cellular proteins for example it up-regulated the levels of "good proteins" such as apoptosis - inducing proteins DR4, DR5, p53, and cleaved caspases-3, -8 , and -9 , and down-regulated the levels of "bad proteins" like cell survival proteins Bcl-2, cFLIP, and GSK-3 $\beta$, in TRAIL-resistant AGS cells. Furthermore, this compound did not affect the viability of noncancerous (HEK293) cells at concentrations up to $30 \mu \mathrm{M}^{27,31}$.

\subsubsection{Anti-platelet activity}

Platelet-activating factor (PAF) involved in both physiological process like platelet aggregation, vascular permeability changes and pathological conditions like thrombosis, inflammation, cardiac anaphylaxis. The extract of $K$. pandurata was reported to be a potential new PAF antagonist with significant inhibitory effect binding to the PAFreceptor $\left(\mathrm{IC}_{50}=8.6 \mu \mathrm{g} / \mathrm{ml}\right)$ and therefore can potentially reduce pathophysiological responses and be applied as therapeutic agents for the treatment of immunological and inflammatory disorders ${ }^{56}$.

\subsubsection{Anti-rheumatic, anti-osteoporosis activity}

Pan et. al. reported that kaempferol (103), flavonoid occurring widely in $K$. rotunda, reduced migration, invasion and matrix metalloproteinases (MMPs) expression in rheumatoid arthritis fibroblast-like synoviocytes (RA-FLSs), dramatically suppressed tumor necrosis factor (TNF)- $\alpha$ - by blocking activation of the MAPK pathway. Kaempferol (103) therefore inhibited cartilage destruction and attenuated the rheumatic artitis progression $^{42}$. 5,7-dimethoxyflavone (87) and $5,7,4$ '-trimethoxyflavone (89), constituents of $K$. parviflora extract also reduced the expression of extracellular MMPs, reduced degradation of collagen within cartilage and thus reduced the pain threshold and severity of osteoarthritic cartilage lesions ${ }^{57}$.

\subsubsection{Anti-oxidant activity}

Studies on biological activities of Kaempferia species showed that both the plant extracts and their 
chemical compositions especially flavonoids possessed anti-oxidant activity. The methanolic extract of $K$. galanga rhizome on DPPH, ABTS and nitric oxide radical scavenging assays showed that its radical scavenging activity increased in concentration-dependent manner and with $\mathrm{IC}_{50}$ values of $16.58, \quad 8.24$ and $38.16 \mu \mathrm{g} / \mathrm{ml}$, respectively $\left(\mathrm{IC}_{50}\right.$ values of positive control catechin were $2.67,4.53$ and $3.18 \mu \mathrm{g} / \mathrm{ml}$, respectively $)^{7}$. Two flavanones, pinostrobin $(\mathbf{8 4})$ and pinocembrin (86) from the rhizomes of $K$. pandurata showed their antioxidant activities against 2,2-diphenyl-1-picrylhydrazyl (DPPH) with $\mathrm{IC}_{50} 6268$ and $5816 \mu \mathrm{mol} / \mathrm{L}^{58}$.

\subsubsection{Anti-inflammatory activity}

The nitric oxide (NO) radical is known to play a central role in inflammatory and immune reactions. Under pathological conditions, it is synthesized in large amount through L-arginine pathway by the catalysis of inducible nitric oxide synthase (iNOS). In the study of Sae-wong et. al., the crude ethanol extract of $K$. parviflora and its constituent (5-hydroxy-3,7,3',4'-tetramethoxyflavone (95)) were investigated for the anti-inflammatory mechanism against (iNOS) and cyclooxygenase-2 (COX-2) mRNA expressions. The results revealed that the ethanol extract of $K$. parviflora markedly inhibited $\mathrm{PGE}_{2}$ release with an $\mathrm{IC}_{50}$ value of 9.2 $\mu \mathrm{g} / \mathrm{ml}$. This plant extract and compound (95) also suppressed mRNA expression of iNOS in dosedependent manners, whereas COX-2 mRNA expression was partly affected. According to the in vivo study, chloroform and hexane fractions greater decreased rat paw edema than the other fractions ${ }^{13}$. Compounds 5-OH-3,7,3',4'-tetramethoxyflavone (95), 5-OH-7,4'-dimethoxyflavone (88) and 5$\mathrm{OH}-3,7,4$ '-trimethoxyflavone (92) isolated from $K$. parviflora showed moderated to mild NO production inhibitory effect with $\mathrm{IC}_{50}=16.1 \mu \mathrm{M}$, $24.5 \mu \mathrm{M}$ and $30.6 \mu \mathrm{M}$, respectively ${ }^{59}$.

Other flavonoids like 5,7-dimethoxyflavone (87), trimethylapigenin (89), and tetramethylluteolin (93), markedly inhibited the production of NO in lipopolysaccharide (LPS)-activated RAW264.7 cells, moderately inhibited production of TNF- $\alpha$ and strongly inhibited expression of iNOS mRNA and iNOS protein in a dose-dependent manner ${ }^{43}$. Trimethylapigenin (89) appeared to be the most abundant compound $(1.29 \%)$ and it also showed interesting biological activity by inhibition of spleen tyrosine kinase (SYK) which plays important role in intracellular signaling cascades like activation of $\mathrm{NF}-\kappa \mathrm{B}$ in inflammatory process ${ }^{43}$.
Tewtrakul et. al. also found that panduratin A (78) isolated from $K$. pandurata rhizome displayed the most potent effect against NO production, with an $\mathrm{IC}_{50}$ value of $5.3 \mu \mathrm{M}$, in comparable to that of caffeic acid phenethylester (CAPE) $\left(\mathrm{IC}_{50}=5.6 \pi \mathrm{M}\right)$. Other compounds such as 4-hydroxypanduratin A (81) and cardamonin (83) showed lower effect with $\mathrm{IC}_{50}$ values $13.3 \mu \mathrm{M}$ and $24.7 \mu \mathrm{M}$, respectively ${ }^{59}$.

In addition, the isolated diarylheptanoids from $K$. galanga rhizome exhibited pronounced inhibitory activities compared with indomethacin on NO production induced by LPS in RAW 264.7 with the most effective $\mathrm{IC}_{50}=26.98 \pm 1.39 \mu \mathrm{M}$ of compound (3R,5S)-3,5-di-hydroxy-1-(3,4dihydroxyphenyl)-7-(4-hydroxyphenyl)heptane (121).

These all results support the use of $K$. parviflora and $K$. pandurata rhizomes in traditional medicine for the treatment of inflammatory - related diseases ${ }^{59}$. Jagadish et al. conducted the study to explore the effect of $K$. galangal obtained from Abirami Botanicals, Tuticorin, Tamilnadu, India and found its effects against acute and chronic inflammation in rats. However the active constituents of the extract and their mechanism of action for the treatment of chronic inflammatory conditions were still unclear ${ }^{30}$.

\subsubsection{Vasorelaxant active and smooth muscle relaxant effects}

Mustafa et al. (1996) reported that the chloroform extract of $K$. galanga inhibits vascular smooth muscle contraction on the precontracted rat thoracic aorta by inhibiting $\mathrm{Ca}^{2+}$ influx through both voltage and receptor-operated non-selective cation channels ${ }^{60}$. Ethyl $p$-methoxycinnamic acid (72), one of major compounds in a crude dichloromethane extract of Kaempferia galanga (24\%, GCMS), also isolated as white needles but did not exhibit any relaxant effect on the precontracted thoracic rat aorta ${ }^{61}$.

\subsubsection{Hepatoprotective activity}

According to Mekjaruskul et. al. $K$. parviflora possessed modulatory effects on hepatic cytochrome P450 enzymes. In his publication, $K$. parviflora extract significantly induced several CYP450 enzyme activities like CYP1A1, CYP1A2 CYP2B, and CYP2E1 activities. CYP1A2 was affected by Kaempferia parviflora with the highest value of $V_{\max }(15.276 \pm 0.206 \mathrm{nmol} / \mathrm{min})$ and lowest of $K_{\mathrm{i}}$ value $(0.008 \pm 0.002 \mu \mathrm{g} / \mathrm{ml})$. Thus, its utilization with drugs or other herbs should raise concern for potential drug-herb interactions ${ }^{11}$.

In another paper, Tsai et. al reported that kaempferol (102) - a flavonoid isolated from 
$K$. rotunda showed protective effect on acute liver injury induced by propacetamol overdose (a prodrug of paracetamol). Kaempferol administration also reduced propacetamolinduced oxidative stress, and changed the level of liver enzymes like downregulating cytochrome P450 2E1 (CYP2E1) expression but upregulation of UDP glucuronosyltransferase family 1 member A1 (UGT1A1) expression. These enzymes play important role in metabolized process (phase I and II) in the liver. This result supposed for an new therapeutic option for treatment of paracetamol-induced hepatotoxicity and protection of acute liver injury ${ }^{62}$.

\subsubsection{Aphrodisiac effects}

Erectile dysfunction (ED) is sexual dysfunction characterized by the inability to develop or maintain an erection off the penis during sexual activity in humans. In order to treat this disorder, many molecular targets are under investigation. Phosphodiesterase 5 (PDE-5) is one of the most protein targeted for this purpose. By inhibition of PDE-5 enzyme, the concentration of intracellular second messenger cGMP (cyclic guanosin 3,5-monophosphatase) will be increased, leading to the relaxation of smooth muscles, improving the blood supply to the corpus cavernosum and consequently improving $\mathrm{ED}^{63}$. Temkitthawon et. al. reported that Kaempferia parviflora rhizome extract and its 7-methoxyflavone (86) constituents had moderate inhibitory activity against PDE- $5^{41}$. Among the tested flavones, 5,7-dimethylflavone (87) seemed to be the most potent PDE-5 inhibitor with $\mathrm{IC}_{50}=10.64 \mu \mathrm{M}$ and 3,5,7,3',4'-pentamethoxyflavone (97) also remarkably inhibited PDE-5 with $\mathrm{IC}_{50}=30.41$ $\mu \mathrm{M}$. Sildenafil was used as positive control with $\mathrm{IC}_{50}=0.0068 \mu \mathrm{M}$. This finding supports that $K$. parviflora can be used in traditional medicine for enhancing sexual performance. Moreover, 5,7-dimethoxyflavones (87) should make a useful lead compound to further develop clinically efficacious PDE5 inhibitors ${ }^{41}$. The components, 5,7-dimethoxyflavone (87) and retusine (95) from $K$. parviflora extract also enhanced testosterone production in mouse testis-derived tumour cells I10via cyclic AMP (cAMP)/cAMP response element binding protein signaling ${ }^{64}$.

\subsubsection{Anti-allergic activity}

PMFs isolated from K. parviflora were found to be capable of inhibiting antigen-stimulated degranulation in rat basophile leukemia RBL-2H3 cells. 5-hydroxy-3,7,4',-trimethoxyflavone (92) and 5,3'-dihydroxy-3,7,4',-trimethoxyflavone (99) showed potent inhibitory activities and these effects were related to the suppression of degranulation due to $\mathrm{Ca}^{2+}$ influx, and translocation of IgE receptor FceRI to the cell surface. The cross-linking of the cellbound IgE-FceRI complex with a specific antigen causes the aggregation of FceRI, which induces a variety of cellular responses, including the release of chemical mediators such as histamine, arachidonic acid metabolites, and cytokines. $K$. parviflora and PMFs may be beneficial for ameliorating the symptoms of type I allergic responses, which is the most common allergic reaction associated with asthma, hives, hay fever, and allergic dermatitis ${ }^{12}$.

Tewrakul et. al. also reported that among the compounds isolated from $K$. parviflora, retusine (95) possessed the highest anti-allergic activity against antigen-induced $\beta$-hexosaminidase release as a marker of degranulation in RBL-2H3 cells with an $\mathrm{IC}_{50}$ value of $8.0 \mu \mathrm{M}$. Two other PMF compounds, 5-hydroxy-7-methoxyflavone (98), and 5-hydroxy-7,4'-dimethoxyflavone (88) also inhibited $\beta$-hexosaminidase release with $\mathrm{IC}_{50}=20.6$ $\mu \mathrm{M}$ and $26.0 \mu \mathrm{M}$, respectively. The findings support the traditional use of $K$. parviflora rhizomes for treatment of allergy and allergy-related diseases ${ }^{37}$.

\subsubsection{Anti-helminthic, anti-amoebic, mosquito repellent and larvicidal activities}

The methanolic extract of $K$. galanga containing cinnamate group as ethyl cinnamate (73), ethyl p-methoxycinnamate (72) and $p$-methoxycinnamic acid (74), was reported to possess larvicidal activity against the second stage larva of dog roundworm, Toxocara canis $^{65}$, against neonate larvae of Spodoptera littoralis ${ }^{34}$, amoebicidal activity against three species of Acanthamoeba including Acanthamoeba culbertsoni, Acanthamoeba castellanii, and Acanthamoeba polyphaga that cause granulomatous amebic encephalitis and amebic keratitis in human ${ }^{65}$. The $K$. galanga extract and fractions also showed repellent activity and larvicidal potency against mosquitos species like Culex quinquefasciatus, Culex gelidus, Culex tritaeniorhynchus Anopheles barbirostris, Anopheles aconitus, Mansonia uniformis, and Aedes aegypt ${ }^{65}$. The working results encourage the use of $K$. galanga as an additional manner in order to control vector-borne diseases by mosquitos like malaria, Dengue fever and Zika disease.

\subsubsection{Skin effect and wound-healing activity \\ Ethanolic extract of $K$. galanga rhizomes}


are used to treat wounds with increase of collagen level ${ }^{66}$. The ethanolic extract of $K$. parviflora rhizomic powder showed an anti-gastric ulcer activity in mice by preservation of gastric mucus secretion and unrelated to the inhibition of gastric acid secretion ${ }^{67}$.

Exposure of ultraviolet (UV) light on the skin induces photoaging associated with upregulation of matrix metalloproteinases (MMP-1) expression through activation of mitogen-activated protein kinases (MAPKs) signal pathways. Hwang et.al. investigated that 4-hydroxypanduratin A (81), isolated from $K$. pandurata, in the range of 0.001$0.1 \mu \mathrm{M}$ significantly reduced the expression of MMP-1 levels, prevented and treated UVassociated skin irritation and aging ${ }^{68}$. He also reserved a patent for this activity of $K$. pandurata and its compounds.

\subsection{Potential application in life of Kaempferia species - derived products: Patents in relation to Kaempferia species}

Patents in relation to the application of Kaempferia species in life have been issued and reserved regionally or globally. Most of these patents are highly practical, applicable and significant in life, which are described as following.

3.5.1. A composition of Kaempferia parviflora extract or flavone compounds for preventing, treating muscle diseases and/or improving muscle function

$K$. parviflora has been commonly used as folk medicine to prevent fatigue and improve physical fitness by some athletes in Asia. In fact, scientific evidences show that application of $K$. parviflora supplements (180 mg of $K$. parviflora extract in capsules) for 12 weeks increased cardiorespiratory fitness, as indicated by increasing $\mathrm{V}_{\mathrm{O} 2}$ max values, increased blood flow to the organs, especially to the muscles, therefore significantly enhance some physical fitness components in soccer players ${ }^{69}$. Hwang et al. in his patent had announced the use of $K$. parviflora Wall. ex. Baker extracts containing active flavone components for improving muscle function, reducing protein catabolism in the muscles and increasing muscle cell differentiation and anabolism. This pharmaceutical composition is thus effective for treating muscle diseases like atony, muscular atrophy/dystrophy, muscle degeneration, myasthenia and sarcopenia, increasing muscle mass and improving muscle function ${ }^{70}$. A herbal formulation containing in $K$. parviflora powder and its active constituent 5,7-dimethoxy flavone in capable of increasing the nitrate and nitrite levels in serum and saliva in human has been invented to improve the general health and enhance the physical endurance or strength of the athletes ${ }^{71}$.

Based on these results, the K. parviflora might be useful in order to recover muscle cell destruction or rhabdomyolysis and compartment syndrome as a serious side effect of lipid lowering drug statins (simvastatin), resulting from drug-drug interactions by co-administration with other drugs like anti-psychotic drug (risperidone) $^{72}$, the platelet inhibitory drug (ticagrelor) $)^{73}$, antifungal agent (itraconazole) ${ }^{74}$.

\subsubsection{The use of Kaempferia extract as pesticide, herbicide compositions}

$K$. galanga extract containing active flavones components ethyl trans-cinnamate (73) and ethyl p-methoxycinnamate (72) in composition with other medicinal plants like slender (Asarum sieboldii), octagonal anise (Illicium verum) and seokchangpo (Acours gramineus) found to have a insecticidal activity against Bursaphelenchus xylophilus, a species of nematode greatly damage to pine trees (Pinus sp.) (pine wood nematode). This invention might provide an environmentallyfriendly nematode control agent for pine forest ${ }^{75}$. $K$. galanga powder in composition with other components like thiophanate-methyl, chlorothalonil, atrazine are effective herbicide with high safety, long efficiency duration, wide weeding range and low cost for protecting crops $^{76}$.

\subsubsection{Using Kaempferia extract and its components} as photo-stable sunscreen, anti-wrinkle, anti-aged cosmetic, skin food and external medical compositions

Gonzalez et. al. in his patent described the extract of $K$. galanga rhizome containing isoamyl p-methoxycinnamate and other compositions as useful as an active photostablized agent and UV absorbency for sunscreen product ${ }^{77}$. This formulation is potential as a photostable, enhanceddegree sunscreen protective and extended for period of time product. Another invention of Chinese authors related to formulations of $K$. galanga extract with sun cream ingredients like glycerin, stearic acid, stearyl alcohol, etc. has been issued to effectively resist the ultraviolet ray and prevent the skin from sunburn ${ }^{78}$. Isoamyl pmethoxycinnamate which is considered to be one of the few compounds which are capable to absorb UV UV-B range (280 to $320 \mathrm{~nm}$ wavelength) and are is produced from $K$. galanga organic solvent extract rich of its precursor p-methoxycinnamate in order by transesterase 
like lipases and esterases to use in cosmetic and pharmaceutical sunscreen preparations ${ }^{79}$.

A patent related to a composition comprising an extract of $K$. parviflora as an active ingredient for skin cosmetic products has been issued by Korean authors. In addition, the extract also exhibits remarkable anti-inflammatory activities by inhibition of tyrosinase activities and NO production. According to the authors, the extract can be usefully used as a pharmaceutical and cosmetic composition for external application with effects in preventing skin-aging and improving skin-whitening ${ }^{80,81}$, used as wrinkle improvement, anti-aging, skin elasticity enhancement, and skin moisturization via the inhibition of moisture loss from the skin ${ }^{82}$. The rhizomic $K$. galanga extract is also used as personal care compositions ${ }^{83}$.

A composition containing $K$. pandurata extract is also used for preventing or treating dermatitis by the expression of cytokines such as IL-1alpha, IL-6, IL-8 and MCP-1 (monocyte chemotactic protein). The $K$. pandurata extract inhibits the sebum secretion by decreasing the activation of PPAR-gamma so that in the form of lotion, astringent, massage cream, pack, powder, body lotion, body cream, rinse and shampoo, the formulation containing $K$. pandurate extract can be used as skin adhesive cosmetic products to control inflammatory skin disease in relation to sebum production disorders ${ }^{84}$.

Composition containing $K$. angustifolia extract is obtained as beautifying and whitening dermal preparation for preventing and reducing pigmentation, dermal stains, ephelides, chloasma ${ }^{85}$.

$K$. galanga rhizome extract is used as ingredients for production of transdermal patches or drug-in-adhesive tape to deliver pain-relief drug through skin ${ }^{86}$. This extract is also used to treat skin irritation or inflammation ${ }^{87}$.

\subsubsection{Using K. parviflora as an effective component for prevention or treatment of thrombosis and health functional food}

The black ginger (Kaempferia parviflora) ethanol extracts and fractions ( $n$-hexane fraction of the hot water extract or ethyl acetate fraction of the ethanol extract) was reserved as an effective component for the prevention and treatment / improved pharmaceutical composition for the thrombosis. The formulation prevented thrombosis through a strong platelet aggregation inhibition, inhibition of thrombosis related enzymes and blood clotting factors ${ }^{88}$. According to the Korean inventors, the formulation from $K$. parviflora improves the blood circulation, treats thrombosis and is useful for disorders such as ischemic stroke and hemorrhagic stroke ${ }^{88}$. A food or drink containing ginger extracts of Zingiberaceae including $K$. parviflora, $K$. galanga, and and several Curcuma sp. with platelet aggregation inhibitory activity has been pronounced in patent of Goto et. al. ${ }^{89}$

\subsubsection{The use of flavone compounds or K. parviflora extract as anti-periodontitis and anti-Alzheimer's compositions}

Flavone compounds from $K$. parviflora extract including 5,7-dimethoxyflavone (87), 5,7,4'-trimethoxyflavone (89) và $3,5,7,3^{\prime}, 4^{\prime}$ pentamethoxyflavone (97) are worthy for the prevention and treatment of periodontal disease by inhibition of the production of collagendecomposing enzyme, and bone resorption enzyme ${ }^{40}$. These compounds are reserved to be active compositions for produce flavone-based or a pharmaceutical formulation or a therapeutic composition for treating periodontal diseases ${ }^{40}$.

Three flavones are also active components in used as anti-aging, skin elasticity enhancement, and skin moisturization compositions ${ }^{82}$. These flavones also pronounced to be potential therapeutic agent / compositions for preventing or treating Alzheimer's dementia by preventing the accumulation of beta-amyloid $(A \beta)$ in brain cells. These natural compounds have no cytotoxicity, and thus have an advantage of least side effects to human in long-term dosage in compare to that synthetic chemical drugs. These flavones according to inventors can be used as medicines and functional health foods for preventing, alleviating, or treating Alzheimer's dementia ${ }^{90}$.

Poly-methoxy flavonoid compound from K. parviflora like apigenin -5,7,4'- trimethyl ether, 3,5,7,3',4'-pentamethylflavone (97), chrysin dimethyl ether; 3,5,7,4' tetramethoxy flavone (89), and 3,5,7, trimethoxyflavon (91) are reserved as sirtuin-activating agent according to patent of Shimada et. al. ${ }^{91}$

\subsubsection{Using Kaempferia extract as drink products}

Chinese inventors in their patents announced to applied $K$. galanga extract with other valuable traditional medicinal plants like angelica (Angelica sinensis, Apiaceae), mulberry (Morus alba, Moraceae), astragalus (Astragalus membranaceous, Fabaceae), poria (Poria cocos, Polyporaceae) etc. to produce oral products to enhance immune function in women ${ }^{92}$. K. parviflora 
extract might be also useful in food processing to provide ginger bitterness, astringency, sweetness and aftertaste for good overall taste to beverage and drink products ${ }^{93} . K$. galanga extract in combination with other fruits, herbs, medicinal plants, vegetable and/or spices is used for making a tea beverage and vegetable broths ${ }^{94}$.

\subsubsection{The use of Kaempferia extract as health food, anti-cold, anti-obesity product}

$K$. parviflora extract in composition with medicinal plant extracts of Zingiber officinale, Cinnamomum cassia, medicinal ginseng, and vitamin B was pronounced to exhibit PPAR $\gamma$ expression, inhibit excessive accumulation of subcutaneous fat and prevent cellulite generation ${ }^{95}$. Another composition of $K$. parviflora extract consisting hops (Humulus lupulus, Cannabaceae), sicklepod (Cassia obtusifolia, Fabaceae), sweet clover (Melilotus officinalis, Fabaceae), ginger (Zingiber officinale, Zingiberaceae) with elastin, gallic acid, caffeine, oligosaccharide, and amino acid was found to exhibit UCP1 (Uncoupling proteins UCPs) expression-promoting effect and/or brown adipocyte differentiation-promoting effect. UCP1 causes the uncoupling of oxidative phosphorylation in the inner mitochondrial membrane of brown adipose cells, which are responsible to provide energy as heat to the body. UCP1 is specifically expressed in brown adipose cells to promote differentiation of precursor cells into brown adipose cells and promote consumption of the neutral lipid into the heat and therefore eliminate obesity ${ }^{96}$. Composition containing extract of black ginger $K$. parviflora can provide heat, promote blood circulation and eliminate coldness for the body ${ }^{97}$.

An extract and/or dried powder of $K$. parviflora has also inhibitory effect against xanthine oxidase is an enzyme that produces uric acid causing gout or hyperuricemia. It also inhibits $5 \alpha$-reductase that causes male pattern baldness and benign prostatic hyperplasia ${ }^{98}$. So, compositions containing $K$. parviflora extract might be a good health product for prevention of diseases associated with obesity and adipose, such as type-2 diabetes mellitus, hypertension, hyperuricemia and hyperlipidemia.

Additionally, several patents related to the cultivation of Kaempferia species in order to obtain Kaempferia plants normally or by tissue culture $^{99}$ with extremely high ornamental value $^{100}$, beautiful plant type and suitable as potted foliage plants ${ }^{101}$, with highly yield of $K$. parviflora black ginger in a shortest time ${ }^{102}$.
The alcohol extract (instead of dichloromethane) of $K$. parviflora, which caused a decrease in visceral and subcutaneous fat, fasting serum glucose and triglyceride levels and liver lipid accumulation, with no changes to liver and kidney functions or to total blood cell counts, can be potentially developed as a health product for mid-aged humans to reduce obesity, diabetes type II and cardiovascular disease ${ }^{103}$.

\section{CONCLUSIONS}

The potential for use of Kaempferia species in everyday life is very large. Kaempferia species like $K$. galanga, $K$. parviflora, $K$. rotunda, etc. are among the most important herbs and widely used in traditional medicines in Asian countries. The Kaempferia in the different formulations like powder, alcohol extracts, maceration, tincture, or water decoctions can be potentially used as food supplements, alternative medicines, and healthcare foods. The water decoctions of $K$. pandurata, $K$. parviflora were used as tonic. $K$. galanga products were used for osteoporosis treatment. These species are also easily cultivated in tropical, sub-tropical but high humidity climate in Asian countries, where many poor people are living. Using the medical products derived from Kaempferia plants will raise economic level and also enhance the life quality of developing countries.

\section{ACKNOWLEDGEMENTS}

Authors acknowledge Prof. Dr. Nguyen Manh Cuong, Institute of Natural Products Chemistry, Vietnam Academy of Science and Technology for his support in preparation this review.

\section{Conflict of interest (If any)}

We authors declare that no conflict of interest in publication of this review.

\section{Funding}

This work was supported by the Institute of Natural Products Chemistry, Vietnam Academy of Science and Technology through Project No. QTSK01.01/21-22 (PI Pham Ngoc Khanh).

\section{Ethical approval}

None to declare.

\section{Article info:}

Received August 6, 2019

Received in revised form November 13, 2019

Accepted March 30, 2020 


\section{REFERENCES}

1. Swapana N, Tominaga T, Elshamy AI, Ibrahim MAA, Hegazy M-EF, Brajakishor Singh C, et al. Kaemgalangol A: Unusual seco-isopimarane diterpenoid from aromatic ginger Kaempferia galanga. Fitoterapia. 2018;129:47-53.

2. Pancharoen $O$, Prawat $U$, Tuntiwachwuttikul P. Phytochemistry of the zingiberaceae. Studies in Natural Products Chemistry. 2000;23:797-865

3. Kumar KMP, Asish GR, Sabu M, Balachandran I. Significance of gingers (Zingiberaceae) in Indian System of Medicine - Ayurveda: An overview. Ancient Science of Life. 2013;32(4):253-61.

4. http://www.theplantlist.org/tpl1.1/search?q=Kaempferia.

5. Abubakara IB, Malami I, Yahaya Y, Sule SM. A review on the ethnomedicinal uses, phytochemistry and pharmacology of Alpinia officinarum Hance. Journal of Ethnopharmacology. 2018;224:45-62.

6. Boonsombat J, Mahidol C, Chawengrum P, Reuk-Ngam $\mathrm{N}$, Chimnoi N, Techasakul S, et al. Roscotanes and roscoranes: Oxygenated abietane and pimarane diterpenoids from Kaempferia roscoeana. Phytochemistry. 2017;143:36-44.

7. Ali H, Yesmin R, Satter MA, Habib R, Yeasmin $T$. Antioxidant and antineoplastic activities of methanolic extract of Kaempferia galanga Linn. Rhizome against Ehrlich ascites carcinoma cells. Journal of King Saud University - Science. 2018;30(3):386-92.

8. Preetha TS, Hemanthakumar AS, Krishnan PN. A comprehensive review of Kaempferia galanga $\mathrm{L}$. (Zingiberaceae): A high sought medicinal plant in Tropical Asia. J Med plants Studies. 2016;4(3):270-6.

9. Sirirugsa P. Taxonomy of the genus Kaempferia (Zingiberaceae) in Thailand. Thai For. Bull. Bot. 1992;19:1-15.

10. Insisiengmay $\mathrm{O}, \mathrm{Haevermans} T$, Newman MF. Typification of names in Kaempferia (Zingiberaceae) in the flora of Cambodia, Laos and Vietnam. PhytoKeys. 2019;122:97-102.

11. Mekjaruskul C, Jay M, Sripanidkulchai B. Modulatory effects of Kaempferia parviflora extract on mouse hepatic cytochrome P450 enzymes. Journal of Ethnopharmacology. 2012;141(3):831-9.

12. Kobayashi S, Kato T, Azuma T, Kikuzaki H, Abe K. Antiallergenic activity of polymethoxyflavones from Kaempferia parviflora. Journal of Functional Foods. 2015;13:100-7.

13. Sae-wong C, Tansakul P, Tewtrakul S. Anti-inflammatory mechanism of Kaempferia parviflora in murine macrophage cells (RAW 264.7) and in experimental animals. Journal of Ethnopharmacology. 2009;124(3):576-80.

14. Tuan NH, Cuong BH. Kaempferia parviflora Wall. ex. Baker - a new record of medicinal plant species for Vietnam. J. Med. Materials. 2016;21(5):293-7.

15. Tuan NH, Duc ND. Kaempferia marginata Carey ex Roscoe (Zingiberaceae) - A new record of medicinal plant species for VietNam. J. Med. Materials. 2017;22(3):322-4.

16. Tuan NH, Duc ND, Nam NH. Kaempferia champasakensis Picheans. \& Koonterm. (Zingiberaceae) - A new record of medicinal plant species for Viet Nam. Bioscience Discovery. 2018;9(3): 356-9.

17. Tuan NH, Nam NH, Duc ND. Kaemferia laotica Gagnep. - A new record of medicinal plant species for Vietnam. J. Med. Materials. 2018;23(4):252-6.

18. Phokham B, Wongsuwan P, Picheansoonthon C. Three new species of Kaempferia (Zingiberaceae) from Thailand and Laos. J. Jpn. Bot. 2013;88:297-308.

19. Picheansoonthon C, Koonterm S. A new species of Kaempferia L. (Zingiberaceae) from Northeastern Thailand. Taiwania. 2009;54(1):52-6.
20. Sirirugsa P. The genus Kaempferia (Zingiberaceae) in Thailand. Nord. J. Bot. 1989;9:257-60.

21. Nopporncharoenkul N, Jenjittikul T. Kaempferia noctiflora (Zingiberaceae), a new species from Northern Thailand. Phytotaxa. 2017;316:67-73.

22. Saensouk S, Saensouk P. Kaempferia phuphanensis (Zingiberaceae), a new species from Thailand. J. Jpn. Bot. 2019;94(3):149-52.

23. Saensouk S, Saensouk P. Kaempferia mahasarakhamensis, a new species from Thailand. Taiwania. 2019;64(1):39-42.

24. Tuấn NH, Trọng NĐ. Kaempferia daklakensis N.H.Tuan $\&$ N.D.Trong (Zingiberaceae) - a new medicinal plant of the Vietnamese flora. Journal of Pharmacology. 2017;490:64-66,79.

25. Chawengrum P, Boonsombat J, Kittakoop P, Mahidol C, Ruchirawat $S$, Thongnest $S$. Cytotoxic and antimicrobial labdane and clerodane diterpenoids from Kaempferia elegans and Kaempferia pulchra. Phytochemistry Letters. 2018;24:140-4.

26. de Paulo Emerenciano V, Scotti M, Stefani R, A. V. Alvarenga S, Nuzillard J-M, V. Rodrigues G. Diterpene skeletal type classification and recognition using SelfOrganizing Maps. Internet Electronic Journal of Molecular Design. 2006;5:213-23.

27. Karmakar UK, Arai MA, Koyano T, Kowithayakorn T, Ishibashi M. Boesenberols I-K, new isopimarane diterpenes from Boesenbergia pandurata with TRAILresistance overcoming activity. Tetrahedron Letters. 2017;58(40):3838-41.

28. Win NN, Ito T, Aimaiti S, Kodama T, Imagawa H, Ngwe H, Asakawa Y, Abe I, Morita H. Kaempulchraols I-O: new isopimarane diterpenoids from Kaempferia pulchra rhizomes collected in Myanmar and their antiproliferative activity. Tetrahedron. 2015;71(29):4707-13.

29. Thongnest S, Mahidol C, Sutthivaiyakit S, Ruchirawat S. Oxygenated pimarane diterpenoids from Kaempferia marginata. J. Nat. Prod. 2005;68:1632-6.

30. Jagadish PC, Latha KP, Mudgal J, Nampurath GK. Extraction, characterization and evaluation of Kaempferia galanga L. (Zingiberaceae) rhizome extracts against acute and chronic inflammation in rats. Journal of Ethnopharmacology. 2016;194:434-9.

31. Karmakar UK, Ishikawa N, Arai MA, Ahmed F, Koyano $\mathrm{T}$, Kowithayakorn $\mathrm{T}$, et al. Boesenberols, pimarane diterpenes with TRAIL-resistance-overcoming activity from Boesenbergia pandurata. J. Nat. Prod. 2016;79(8):2075-82.

32. Huang L, Yagura T, Chen S. Sedative activity of hexane extract of Keampferia galanga L. and its active compounds. Journal of Ethnopharmacology. 2008;120(1):123-5.

33. Seaman F, Bohlmann F, Zdero C, Mabry TJ. Diterpenes of flowering plants: Compositae (Asteraceae). SpringerVerlag New York, Berlin, Heidelberg, London, Paris, Tokyo, Hong Kong. 1990;485-506.

34. Pandji C, Grimm C, Wray V, Witte L, Proksch P. Insecticidal constituents from four species of the zingiberaceae. Phytochemistry. 1993;34(2):415-9.

35. Hwang J-K, Chung J-Y, Baek N-I, Park J-H. Isopanduratin A from Kaempferia pandurata as an active antibacterial agent against cariogenic Streptococcus mutans. International Journal of Antimicrobial Agents. 2004;23(4):377-81.

36. Pancharoen O, Picker K, Reutrakul V, Taylor WC, Tuntiwachwuttikul P. Constituents of the Zingiberaceae. X Diastereomers of [7-Hydroxy-5methoxy- 2-methyl-2-(4' -methylpent-3' -enyl)- $2 \mathrm{H}$ chromen-8-yl] [3 -methyl-2" (3" -methylbut-2 -enyl)-6" -phenylcy clo- hex-3"-enyljmethanone (Panduratin B), a Constituent of the Red Rhizomes of a Variety of Boesenbergia pandurata. Aust J Chem. 1987;40(3):455-9. 
37. Tewtrakul S, Subhadhirasakul S, Kummee S. Antiallergic activity of compounds from Kaempferia parviflora. Journal of Ethnopharmacology. 2008;116(1):191-3.

38. Jaipetch T, Reutrakul V, Tuntiwachwuttikul P, Santisuk T. Flavonoids in the black rhizomes of Boesenbergia panduta. Phytochemistry. 1983;22(2):625-6.

39. Atun S, Arianingrum R, Sulistyowati E, Aznam N. Isolation and antimutagenic activity of some flavanone compounds from Kaempferia rotunda. International Journal of Chemical and Analytical Science. 2013;4(1):3-8.

40. Anonymous Anti-periodontitis composition comprising flavone compounds or Kaempferia parviflora extract. KR101647495B1. 2014.

41. Temkitthawon P, Hinds TR, Beavo JA, Viyoch J, Suwanborirux K, Pongamornkul W, et al. Kaempferia parviflora, a plant used in traditional medicine to enhance sexual performance contains large amounts of low affinity PDE5 inhibitors. Journal of Ethnopharmacology. 2011;137(3):1437-41.

42. Pan D, Li N, Liu Y, Xu Q, Liu Q, You Y, et al. Kaempferol inhibits the migration and invasion of rheumatoid arthritis fibroblast-like synoviocytes by blocking activation of the MAPK pathway. International Immunopharmacology. 2018;55:174-82.

43. Sae-Wong C, Matsuda H, Tewtrakul S, Tansakul P, Nakamura S, Nomura Y, et al. Suppressive effects of methoxyflavonoids isolated from Kaempferia parviflora on inducible nitric oxide synthase (iNOS) expression in RAW 264.7 cells. Journal of Ethnopharmacology. 2011;136(3):488-95.

44. Kim M, Choi S, Noh K, Kim C, Kim E, Hwang J-K, Kang W. Determination of panduratin $\mathrm{A}$ in rat plasma by HPLC-MS/MS and its application to a pharmacokinetic study. J Pharmaceu Biomed Anal. 2017;137(15):151-4

45. Azuma T, Tanaka Y, Kikuzaki H. Phenolic glycosides from Kaempferia parviflora. Phytochemistry. 2008;69(15):2743-8.

46. Pancharoen O, Tuntiwachwuttikul P, Taylor WC. Cyclohexane diepoxides from Kaempferia rotunda. Phytochemistry. 1996;43(1):305-8.

47. Yao F, Huang Y, Wang Y, He X. Anti-inflammatory diarylheptanoids and phenolics from the rhizomes of kencur (Kaempferia galanga L.). Industrial Crops and Products. 2018;125:454-61.

48. Ridtitid W, Sae-wong C, Reanmongkol W, Wongnawa M. Antinociceptive activity of the methanolic extract of Kaempferia galanga Linn. in experimental animals. Journal of Ethnopharmacology. 2008;118(2):225-30.

49. Wong KC, Ong KS, Lim CL. Compositon of the essential oil of rhizomes of Kaempferia galanga L. Flavour and Fragrance Journal. 1994;7(5):263-6.

50. Shetu HJ, Trisha KT, Sikta SA, Anwar R, Rashed SSB, Dash PR. Pharmacological importance of Kaempferia galanga (Zingiberaceae): A mini review. International Journal of Research in Pharmacy and Pharmaceutical Sciences. 2018;3(3):32-9.

51. Sukandar EY, Sunderam N, Fidrianny I. Activity of Kaempferia pandurata (Roxb.) rhizome ethanol extract against MRSA, MRCNS, MSSA, Bacillus subtilis and Salmonella typhi. Pakistan journal of biological sciences: PJBS. 2014;17(1):49-55.

52. Limsuwan S, Voravuthikunchai SP. Bactericidal, bacteriolytic, and antibacterial virulence activities of Boesenbergia pandurata (Roxb) Schltr extract against Streptococcus pyogenes. Trop J Pharm Res. 2013;12(6):1023-8.

53. Miksusanti, Jenie BSL, Priosoeryanto BP, Syarief R,
Rekso GT. Mode of action temu kunci (Kaempferia pandurata) essential oil on $E$. coli $\mathrm{K} 1.1$ cell determined by leakage of material cell and salt tolerance assays. HAYATI Journal of Biosciences. 2008;15(2):56-60.

54. Ichwan SJA, Husin A, Suriyah WH, Lestari W, Omar MN, Kasmuri AR. Anti-neoplastic potential of ethyl-pmethoxycinnamate of Kaempferia galanga on oral cancer cell lines. Materials Today: Proceedings. 2019;16:2115-21.

55. Murata K, Hayashi H, Matsumura S, Matsuda H. Suppression of benign prostate hyperplasia by Kaempferia parviflora rhizome. Pharmcognos Res. 2013;5(4):309-14.

56. Jantan I, Rafi IAA, Jalil J. Platelet-activating factor (PAF) receptor-binding antagonist activity of Malaysian medicinal plants. Phytomedicine. 2005;12(1-2):88-92.

57. Kobayashi H, Suzuki R, Sato K, Ogami T, Tomozawa $\mathrm{H}$, Tsubata $\mathrm{M}$, et al. Effect of Kaempferia parviflora extract on knee osteoarthritis. J Nat Med. 2018;72(1f):136-44

58. Tanjung M, Tjahjandarie TS, Sentosa MH. Antioxidant and cytotoxic agent from the rhizomes of Kaempferia pandurata. Asian Pacific Journal of Tropical Disease. 2013;3(5):401-4.

59. Tewtrakul S, Subhadhirasakul S, Karalai C, Ponglimanont C, Cheenpracha S. Anti-inflammatory effects of compounds from Kaempferia parviflora and Boesenbergia pandurata. Food Chem. 2009;115(2):534-8.

60. Mustafa MR, Mustafa AM, Hashim S. Vasorelaxant effects of the chloroform extract of Kaempferia galanga on smooth muscles of the rat aorta (Article) Asia Pacific Journal of Pharmacology. 1996;11(3-4):97-101.

61. Othman R, Ibrahim H, Mohd MA, Mustafa MR, Awang $\mathrm{K}$. Bioassay-guided isolation of a vasorelaxant active compound from Kaempferia galanga $\mathrm{L}$. Phytomedicine. 2006;13:61-6.

62. Tsai MS, Wang YH, Lai YY, Tsou HK, Liou GG, Ko JL, et al. Kaempferol protects against propacetamolinduced acute liver injury through CYP2E1 inactivation, UGT1A1 activation, and attenuation of oxidative stress, inflammation and apoptosis in mice. Toxicology Letters. 2018;290:97-109.

63. Khanh PN, Huong TT, Spiga O, Trezza A, Son NT, Cuong TD, et al. In silico screening of anthraquinones from Prismatomeris memecyloides as novel phosphodiesterase type-5 inhibitors (PDE-5Is). Revista Internacional de Andrología. 2017;16(4):147-58.

64. Horigome S, Maeda M, Ho HJ, Shirakawa H, Komai M. Effect of Kaempferia parviflora extract and its polymethoxyflavonoid components on testosterone production in mouse testis-derived tumour cells. Journal of Functional Foods. 2016;26:529-38.

65. Kanjanapothi D, Panthong A, Lertprasertsuke N, Taesotikul T, Rujjanawate C, Kaewpinit D, et al. Toxicity of crude rhizome extract of Kaempferia galanga L. (Proh Hom). Journal of Ethnopharmacology. 2004;90(2):359-65.

66. Shrivastav A, Mishra AK, Ali SS, Ahmad A, Abuzinadah MF, Khan NA. In vivo models for assesment of wound healing potential: A systematic review. Wound Medicine. 2018;20:43-53.

67. Rujjanawate C, Kanjanapothi D, Amornlerdpison D, Pojanagaroon S. Anti-gastric ulcer effect of Kaempferia parviflora. Journal of Ethnopharmacology. 2005;102(1):120-2.

68. Shim JS, Han YS, Hwang JK. The effect of 4hydroxypanduratin $\mathrm{A}$ on the mitogen-activated protein kinase-dependent activation of matrix metalloproteinase-1 expression in human skin 
fibroblasts. J Dermatolog Sci. 2009;53(2):129-34.

69. Promthep K, Eungpinichpong W, Sripanidkulchai B, Chatchawan U. Effect of Kaempferia parviflora extract on physical fitness of soccer players: A randomized double-blind placebo-controlled trial. Medical Science Monitor Basic Research. 2015;21:100-8.

70. Hwang JK, Sa BK, Kim TY. Use of Kaempferia parviflora Wall. ex. Baker extracts or flavone compound for preventing or treating muscle diseases, or improving muscle function US 9,669,066 B2 / WO 2013/172681 A1, 2017 June 6.

71. Gopi S, Covilakam KVA, Jacob J. A formulation for improving physical endurance in athletes and a method for preparing the samea formulation for improving physical endurance in athletes and a method for preparing the same. WO2018033892A1. 2016.

72. Webber MA, Mahmud W, Lightfoot JD, Shekhar A. Rhabdomyolysis and compartment syndrome with coadministration of risperidone and simvastatin. Journal of psychopharmacology (Oxford, England). 2004;18(3):432-4.

73. Mrotzek SM, Rassaf T, Totzeck M. Ticagrelor Leads to Statin-Induced Rhabdomyolysis: A Case Report. The American journal of case reports. 2017;18:1238-41.

74. Dybro AM, Damkier P, Rasmussen TB, Hellfritzsch M. Statin-associated rhabdomyolysis triggered by drug-drug interaction with itraconazole. BMJ Case Report. 2016.

75. Park IK Nematocides containing plant extracts and components isolated from Kaempferia galanga for the control of nematode. KR100764482B1. 2006.

76. Anonymous Special herbicide for Kaempferia galanga. CN106665626A. 2016.

77. Gonzalez AD, Pechko AH, Kalafsky RE. Photostable sunscreen compositions and methods of stabilizing. 2002.

78. Anonymous Glycerin and Kaempferia galanga sun cream. 2008

79. Gatfield ID, Hall R, Kaiser RD, Langner R, Surburg HD. Isoamyl p-methoxycinnamate of natural origin, production of higher p-methoxycinnamic acid esters by natural process and their use as UV-filters. EP0795315A2. 1996.

80. Anonymous A Composition comprising an extract of Kaempferia parviflora as an active ingredient for preventing skin aging and improving skin whitening. 2012.

81. Anonymous Cosmetic Composition for Skin Whitening Having Kaempferia parviflora. KR101551240B1.

82. Hwang JK, Kim J. Novel use of flavone-based compound. US20140148504A1. 2011.

83. Osborne R Personal care compositions. 2009.

84. Anonymous Compositions containing Kaempferia pandurata extract for preventing or treatment skin disease. KR20090093477A. 2008.

85. Okihiko S, Naomi T, Eiichiro Y, Yoshihiro Y. Beautifying and whitening dermal preparation for external use. JPH0930948A. 1995.

86. Mitroo S. Tape having transdermal analgesic properties. US20160128950A1. 2013.

87. Collins DF, Maes DM, Muizzuddin N. Methods and compositions for treating skin. US 2015/0132401 A1. 2015.

88. Anonymous Pharmaceutical composition comprising the extraction of Kaempferia parviflora as an effective component for prevention or treatment of thrombosis and health functional food comprising the same.

89. Goto Y, Kumagai H, Masuda H, Matsui Y, 熊谷 秀増後松 Platelet aggregation inhibitor. JP2012153671A. 2011.

90. Anonymous Composition for preventing or treating Alzheimer's disease comprising compounds from Kaempferia parviflora. KR20150040618A. 2013.

91. Anonymous Sirtuin activator. 2011.

92. Anonymous Application of Kaempferia galanga L extract in health food. CN103652922B. 2013.

93. Rika A, Hiromoto K. Kaempferia parviflora extract composition, Kaempferia extract-containing food and drink and method for improving the taste of Kaempferia parviflora extract. JP2014121332A. 2014.

94. Ragot P, Mompon B, Rousseau C, Pons E, Pineau C. Composition for making tea beverage or herbal and vegetable broths. US 2014/0295049 A1. 2014.

95. Takatoshi O, Ayumi N, Seiichi K, Kinya T. Kaempferia parviflora containing PPARg expression promoting composition. JP2016056163A. 2015

96. Takatoshi O, Ayumi N, Seiichi K, Kinya T. Kaempferia parviflora-containing compositions. JP2017088616A. 2017.

97. Matsunaga K, 松永勝. Composition for improving cold constitution. JP2009067731A. 2007.

98. Takanori F, Hideaki M, Shinichi M, Masayuki T, Yuri Y. Kaempferia parviflora - enzyme inhibitor having xanthine oxidase inhibition activity and $5 \alpha$-reductase inhibition activity, and food and drink, cosmetic composition and pharmaceutical composition containing the enzyme inhibitor. JP2011236133A. 2010.

99. Anonymous Method for inducing regenerated plant from blastema part of Kaempferia rotunda rhizome. CN107182783A. 2017.

100.Anonymous Potted cutting propagation method of Kaempferia elegans. 2017.

101. Anonymous Species potted dwarf method Kaempferia rotunda. CN108293824A, 2017.

102.Kobayashi M, Hitomi N. Method of cultivating black ginger. JP2013132257A. 2011.

103. Yorsin S, Kanokwiroon K, Radenahmad N, Jansakul C. Effects of Kaempferia parviflora rhizomes dichloromethane extract on vascular functions in middle-aged male rat. Journal of Ethnopharmacology. 2014;156:162-74. 